Review

\title{
Fungal Cell Wall Proteins and Signaling Pathways Form a Cytoprotective Network to Combat Stresses
}

\author{
Chibuike Ibe $^{1, *(1)}$ and Carol A. Munro ${ }^{2}$ \\ 1 Department of Microbiology, Faculty of Biological Sciences, Abia State University, Uturu 441107, Nigeria \\ 2 Aberdeen Fungal Group, Institute of Medical Sciences, School of Medicine, Medical Sciences and Nutrition, \\ University of Aberdeen, Aberdeen AB24 3FX, UK; c.a.munro@abdn.ac.uk \\ * Correspondence: c.ibe@abiastateuniversity.edu.ng
}

Citation: Ibe, C.; Munro, C.A. Fungal Cell Wall Proteins and Signaling Pathways Form a Cytoprotective Network to Combat Stresses. J. Fungi 2021, 7, 739. https://doi.org/ 10.3390/jof7090739

Academic Editors: María Molina and Humberto Martín

Received: 29 July 2021

Accepted: 4 September 2021

Published: 8 September 2021

Publisher's Note: MDPI stays neutral with regard to jurisdictional claims in published maps and institutional affiliations.

Copyright: (C) 2021 by the authors. Licensee MDPI, Basel, Switzerland. This article is an open access article distributed under the terms and conditions of the Creative Commons Attribution (CC BY) license (https:// creativecommons.org/licenses/by/ $4.0 /)$.

\begin{abstract}
Candida species are part of the normal flora of humans, but once the immune system of the host is impaired and they escape from commensal niches, they shift from commensal to pathogen causing candidiasis. Candida albicans remains the primary cause of candidiasis, accounting for about $60 \%$ of the global candidiasis burden. The cell wall of C. albicans and related fungal pathogens forms the interface with the host, gives fungal cells their shape, and also provides protection against stresses. The cell wall is a dynamic organelle with great adaptive flexibility that allows remodeling, morphogenesis, and changes in its components in response to the environment. It is mainly composed of the inner polysaccharide rich layer (chitin, and $\beta$-glucan) and the outer protein coat (mannoproteins). The highly glycosylated protein coat mediates interactions between $C$. albicans cells and their environment, including reprograming of wall architecture in response to several conditions, such as carbon source, $\mathrm{pH}$, high temperature, and morphogenesis. The mannoproteins are also associated with $C$. albicans adherence, drug resistance, and virulence. Vitally, the mannoproteins contribute to cell wall construction and especially cell wall remodeling when cells encounter physical and chemical stresses. This review describes the interconnected cell wall integrity (CWI) and stress-activated pathways (e.g., Hog1, Cek1, and Mkc1 mediated pathways) that regulates cell wall remodeling and the expression of some of the mannoproteins in C. albicans and other species. The mannoproteins of the surface coat is of great importance to pathogen survival, growth, and virulence, thus understanding their structure and function as well as regulatory mechanisms can pave the way for better management of candidiasis.
\end{abstract}

Keywords: fungi; cell wall; cell wall proteins; signaling pathways; stress tolerance

\section{Introduction}

Candida albicans is abundantly found in mammals. It often resides on the skin and mucosal layers of individuals as part of their normal flora. C. albicans causes a range of infections from superficial to life-threatening and systemic, dependent upon the host's immune system [1] C. albicans uses an arsenal of pathogenic mechanisms to subdue or evade host immune responses [2,3]. The mannosylated surface protein coat is covalently linked to the skeletal cell wall polysaccharides and plays a vital role in mediating C. albicans interaction with the host. The proteins are not only important in maintaining cell wall integrity, masking the polysaccharide rich layer, therefore preventing recognition by dectin1 , but also contribute to virulence of this pathogen in many ways. They mediate adherence to host cells and indwelling medical devices, enable invasion of epithelial cells, facilitate biofilm formation, protect $C$. albicans against immune attack, coordinate communication between host cells and C. albicans, and are important in nutrient scavenging including zinc and iron [3]. Given the important roles of the cell surface proteins at every stage of C. albicans infection process, research has been focused on expanding our understanding of their biology and structure as well as their function in the cell wall [4]. This area is, 
however, rapidly expanding as the cell surface proteins have the potential to be a unique drug/vaccine target [5-7]. Proteomics analysis of purified cell wall material has shown that the walls contain about 20 different types of covalently bound cell wall proteins (CWPs) at any time and the protein profiles can change dramatically depending on the growth conditions [8]. In addition, the presence of particular cell surface proteins morphologically depends and correlates with either C. albicans yeast or hyphal form [8]. The aim of this review is to discuss the characteristics and functions of covalently bound CWPs, and how they are important for fitness and virulence, and enable the fungus to cope with host infection-induced stress conditions. The review will also discuss the regulatory mechanisms that control expression of cell wall-related genes and relate what is known in C. albicans and other Candida species.

\section{Function of Cell Wall Proteins}

Based on the existing model of the cell wall, it is made up of an inner polysaccharide rich layer and the outer protein coat [9-11]. A 3-D nanoscalar model of the C. albicans cell wall has been developed to probe accurate thickness and structure of the cell wall $[4,10]$. The investigators used an optimized 3-D electron tomogram and computer vision technique to make accurate measurements of cell wall thickness [4]. The scalar model developed gave a more refined prediction of the thickness of each cell wall layer and the precise structure of some of the wall components [4]. The inner layer of the cell wall is composed mainly of $\beta$-glucans ( $\beta$-1,3-glucan and $\beta$-1,6-glucans), chitin microfibrils, and a small amount of mannosylated proteins is distributed throughout the inner layer [4]. Chitin ( $\beta-1,4-\mathrm{N}$-acetyl glucosamine) and $\beta$-glucans ( $\beta$-1,3-glucan) are the main structural polysaccharides of the cell wall [12]. $\beta$-1,3-glucan forms a three-dimensional network comparable to a flexible wire spring, which explains the elastic nature of the cell wall and provides the platform for the attachment of $\beta$-1,6-glucan, CWPs, and chitin [13]. Chitin is covalently cross-linked to the $\beta$-1,3-glucan network and contributes to the rigidity and physical strength of the fungal cell wall [12]. The outer coat is made up of glycan fibrils post-translationally attached to CWPs that are vertically arranged perpendicular to the inner layer [4].

The outer coat of mannoproteins determines cell wall permeability and surface charge [9]. Restriction of cell wall permeability is due to the densely packed CWPs, the presence of bulky protein sidechains, and the formation of disulfide bridges between CWPs $[12,14,15]$. This feature protects the structural polysaccharides against enzyme degradation and dectin-1 receptor recognition $[15,16]$. The use of genomic and proteomic techniques has advanced our knowledge of the nature and abundance of these surface proteins. CWPs have a unique structure, they generally contain: an $\mathrm{N}$ terminus with a secretory motif and a C terminus [17]. They bear serine/threonine-O-manno-oligosaccharide and/or asparagine- $\mathrm{N}$-glycan and may contain internal repeats and/or a glycosylphosphatidylinositol, GPI anchor attachment sequences $[18,19]$. The most abundant cell proteins are the GPI-modified proteins, which receive a GPI anchor during their passage through the secretory pathway [20-24] and constitute about $88 \%$ of the total wall mannosylated protein classes [25] (Table 1). The second class of CWPs are those with internal repeats, PIR-CWPs [18,26] (Table 1). 
Table 1. Characteristics of specific Candida albicans surface proteins.

\section{Protein/Family \\ GPI modified CWPs \\ Adhesins, invasins}

Als family (Als1-7,9)

Hwp1, Hwp2, Eap1, Ihd1, and Hyr1

\section{Carbohydrate active enzymes} 1,3- $\beta-$-Glucan processing
Phr1-3, Pga4, and Pga5

\section{Chitin-glucan} cross-linkersChr family

\section{Others \\ Dfg5 and Dcw1}

Pga31-like (Pga29-31)

Sod 4 and Sod5

Sap9 and Sap10

Pga59

Rbt5, Pga10, and Pga7

\section{Non-GPI modified CWPs}

Pir1
Features and Functions

N-terminal c. 300-residue Ig domain, bind variety of substrates [27,28]; high (Als1, Als2), intermediate (Als4, Als9), and low (Als5-7) levels of gene expression [27,29-31]. Als3 is expressed uniformly all over hyphae [32]. Als1 and Als3 $\mathrm{N}$ terminal sequences are used as vaccine antigen [7]. Als1 and Als3 contribute to biofilm formation, and Als3 functions as an invasin, and as a ferritin receptor $[27,30,31,33]$.

Hwp1 level is induced by oxygen and iron restriction [38]. $\mathrm{N}$ terminal is recognised as substrate for epithelial transglutaminases [39]. Hwp1 facilitates cell to cell interaction important in biofilm development [33]. $\mathrm{N}$ terminal 14-mer peptide and recombinant $\mathrm{N}$ terminal fragment are used in vaccine and diagnostic development, respectively [40,41].

Hwp2 has sequence identity with Hwp1 and can function in adhesion and invasion; it is also involved in oxidative stress tolerance and protein aggregation $[42,43]$. Hwp1, Hwp2, Eap1, and Ihd1 contribute to initial cell attachment and adhesion maintenance during biofilm formation [44]. $\mathrm{N}$ terminal of Hyr1 has been used in vaccines and diagnostics development $[5,45]$.

$\mathrm{N}$ terminal glycoside hydrolase $(\mathrm{GH}) 72$ domain; play a role in cell wall construction ( $\beta-1,3$-glucan modification); incorporated at acidic $\mathrm{pH}(\mathrm{Phr} 2)$ and neutral/alkaline $\mathrm{pH}(\mathrm{Phr} 1)[45,46]$. Pga4 is transcribed independent of $\mathrm{pH}$, and Phr3 and Pga5 have low expression levels [47]. Pga4 is serum- and host infection-inducible [48].

$\mathrm{N}$ terminal GH16 domain; involved in cell wall organization and integrity; cross-linking $\beta$-1,3-glucan and chitin; involved in protoplast regeneration [50,51]. Control cell wall elasticity in osmotic resistance [52].

Putative glycosyltransferase enzyme activity; involved in the incorporation of GPI anchored proteins into the cell wall $[55,56]$. Dfg5 and Dcw1 are involved in hyphal morphogenesis and biofilm formation; Dfg5 is required for growth Dcw1 is required for cell wall integrity response; Dfg5 has synthetic lethality with Dcw1 [56].

Enriched in pathogenic fungi [57]. Pga31 has predicted transmembrane domain and with Pga30 they have three conserved cysteine residues (http: / / www.candidagenome.org/ (accessed on 12 July 2021)). Pga29 and Pga31 are echinocandin induced; Pga29 is required for normal cell surface property [58]. Pga31 is induced during protoplast regeneration [59] and may be involved in cell wall chitin synthesis during remodelling in response to stress [60].

Superoxide dismutase; contribute to combating oxidative stress by clearing reactive oxygen species [61].

Yapsin-like proteins are mainly found in the cell membrane (Sap9) and cell wall (Sap10); required for full cell wall integrity [63].

Cell wall localised [64]; abundant in the cell wall protein coat; mature protein consists of three cysteine residues and cross-links cell wall proteins through disulphide bridges [64].

$\mathrm{N}$ terminal CFEM domain; cell membrane (Pga7 and Rbt5) localised; loss of function results in fragile biofilms (Pga10 and Rbt5) [65,66]; function as haeme receptors and involved in haeme-iron utilization $[67,68]$. Rbt5 levels increase following iron and oxygen restriction [38].

$C$ terminal conserved four cysteine pattern and seven repeats; predicted to cross-link $\beta$-1,3-glucan chains [69]; protein levels increase in hypoxic conditions [38].

$\mathrm{C}$ terminal $\mathrm{GH} 17 \mathrm{z}$ domain; present in fibrillar material with putative transglycosylase activity; potential vaccine candidate [70].
Regulation

Als proteins are differentially expressed, ALS1, ALS3, and HWP1 are under the positive regulatory control of Bcr1 [34-36]. Tup1 (repressor of filamentation] and Ahr1 are required for full expression of ALS3 [37].

PHR1 and PHR2 are differentially regulated by extracellular $\mathrm{pH}$ [49].

UTR2 expression is regulated by calcineurin and Crz1 [53]. CRH11 is subject to caspofungin-induced Cas5 regulation [54]

DFG5 has been shown to be regulated by $\mathrm{R} \operatorname{lm} 1$ in $S$. cerevisaie, but not in C. albicans [54].

PGA31 is upregulated by the Pkc pathway [60].

Rim101 is required for induction of SOD5 under certain conditions, and Efg1 is required specifically for serum-modulated expression [62].

The proteins have been shown to be expressed during yeast to hyphae switch and thus are regulated by Tup1 [66]. 
A 3-D electron tomogram was used to determine the structure of the outer coat of mannosylated proteins. The scalar architectural model of mannosylated proteins gave a more precise detail of their structure, location and molecular size including measurements of their length and branching $[4,71]$. The cell wall through the outer proteins mediates host pathogen-interaction. The scalar architectural model may be useful in investigating the structure-function relationships that support the fungal infection strategy $[4,10]$.

CWPs have both enzymatic and structural functions and their population may differ in their abundances depending on environmental conditions, developmental stage and phase of the cell cycle [9]. During cell wall synthesis, the cell wall polysaccharides, chitin and $\beta$ 1,3-glucan are synthesized by enzymes localized in the plasma membrane and are extruded out to the cell exterior and are then acted upon by wall-localized cell wall remodeling enzymes [17]. CWPs modify these cell wall polysaccharides and cross-link them, thus maintaining cell wall integrity [9]. The cross-linking between cell wall macromolecules extruded into the wall space is catalyzed by carbohydrate active cell wall remodeling enzymes, hydrolases, transferases, and transglycosidases that are located in the cell wall space $[17,72]$. Some of these enzymes include $\beta$-1,3-glucanosyltransferases, e.g., Phr family (see Table 1), which are a Gas-like family, Bgl2 (GH17), and Crh family representing chitinglucanosyltransferases, these are cell wall-localized GPI anchored proteins [17,50,51,73-76]. C. albicans phr1 $\Delta / \Delta$ and $p h r 2 \Delta / \Delta$ mutants showed hypersensitivity to cell wall stressors such as Calcofluor white, CFW [45]. In C. albicans, synthetically lethal GPI-anchored proteins such as Dfg5 and Dcw1 (glycoside hydrolase (GH) family 76) are required for the incorporation of mannosylated proteins into the cell wall [55].

Structural surface proteins with no enzymatic activities such as flocculins (e.g., Flo1, Pga24), agglutinins (e.g., Als1, Rbt1, Hwp1), or $\beta$-1,3-glucan cross connectors (e.g., Pir1) that can form a scaffold for the attachment of other wall components, are important for cell:cell interactions and wall integrity [27,30,31,33,77-81]. Ssr1, a structural protein has been shown to contribute to normal cell wall architecture [82]. Pga59 is thought to be associated with the formation of a coat around the cell wall that can restrict cell wall permeability [64]. CWPs are also associated with virulence, biofilm formation, and coping with stress in fungi $[33,36,61,67,68,83-85]$. The following are some examples. The ALS gene family encodes eight GPI modified cell surface glycoproteins with peptide binding ability Ig-fold domain at the $\mathrm{N}$ terminus [86]. The Ig-fold mediates adhesion to fibronectin and other specific host proteins [87], and cell to cell aggregation through Als to Als interaction (Nobile et al., 2008). Heterologous expression of Als proteins in a nonadherent S. cerevisiae strain demonstrated that the Als proteins promote attachment to different surfaces (Nobile et al., 2008). The als3 $\Delta / \Delta$ mutant has reduced virulence in a murine model of oropharyngeal candidiasis [31]. Hwp1 $\mathrm{N}$ terminus contains a secretory signal sequence rich in proline and glutamine that is cross-linked by host transglutaminase to epithelial cells enabling the attachment of C. albicans to human buccal epithelial cells $[39,88,89]$. C. albicans hwp $1 \Delta$ mutant has reduced ability to bind to human buccal epithelial cells and has poor translocation from the mouse intestine into the bloodstream, demonstrating a role for Hwp1 in disseminated candidiasis [31]. Attachment to host cells by C. albicans can also be due to morphology-independent covalently bound wall proteins, Hyr1, Ecm33, Iff4, and Eap1, covalently bound wall proteins, Phr1, and cell-surface associated proteases, Sap9 and Sap10 [90,91].

C. albicans can use endocytosis (through interaction of Als3 with host cadherins) or active penetration to invade the host cell [31]. After C. albicans adhesion to the host cell surface and hyphal germination and growth, there are hyphal-induced hydrolytic enzymes that facilitate host cell degradation. They particularly aid active penetration into host cells and damage tissues [92].

C. albicans expresses ten secreted aspartyl proteinase (Sap) isoenzymes. Each mature Sap protein contains two aspartic acid residues conserved within the active site and a conserved cysteine residue that plays a structural role. Sap1-8 are secreted and released to the environment, whereas Sap 9 and Sap10 are cell surface bound $[63,93,94]$. Sap proteins 
have been linked to the ability of $C$. albicans to adhere to and damage host tissue as well as the ability to evade the host immune response [95]. Sap9 and Sap10 have proteolytic activity on non-basic, basic, and dibasic peptides and have targeted Cht2, Ecm33, Pga4, Ywp1, Als2, Rhd3, Rbt5, and glucan cross-linked protein, Pir1 as substrates. C. albicans sap $9 \Delta / \Delta$ and sap $10 \Delta / \Delta$ mutants demonstrated reduction in cell wall-associated Cht2 activity suggesting a direct influence of Sap9 and Sap10 activity on Cht2 function and a role in maintaining cell wall integrity [96].

During C. albicans infection, Als family, and Eap1 adhesin, are involved in the development of biofilms, an important virulent attribute. The fungus forms biofilms when it encounters solid surfaces such as indwelling medical devices, where fungal cells are encapsulated in a dense extracellular matrix, which sequesters antifungal drugs promoting drug resistance and persistence in the host $[97,98]$. Biofilm formation by C. albicans has been shown to be under the positive regulatory control of the transcription factor, Bcr1. Bcr1 regulates the expression of Als1, Als3, and Hwp1 [34-36]. These proteins in addition to Als2 are associated with various stages of biofilm formation in C. albicans [28,99].

The cell wall during growth requires continuous remodeling of its macromolecular network [17]. During cell wall stress, a fungus can also rapidly remodel its wall and adapt the composition of the new cell wall [52,73,100]. For example, in exposure to cell damaging antifungal drugs, C. albicans triggers cell wall rescue mechanisms that influence the expression of wall biosynthetic genes and CWPs $[4,60,101]$. Rescuing the cell wall requires stress signals that activate the cell wall integrity (CWI) pathways. Cell surface proteins that function as mechanosensors primarily are responsible for activating these CWI pathways. These proteins (Wsc1-3 and Mtl1) act like linear nanosprings that detect and transmit cell wall damage or stress [102-105] to the downstream receptors in the signaling pathways. The sensors have an overall similar structure in that they contain in their sequences: short $C$ terminal cytoplasmic domains, a single transmembrane domain, and a periplasmic ectodomain that is rich in Ser/Thr residues [106]. The Ser/Thr-rich regions are highly $O$-mannosylated, accounting for extension and stiffening of the proteins. Thus, these polypeptides have been proposed as mechanosensors that act as rigid probes of the extracellular matrix [106,107]. Functionally, signals are received and transmitted through the highly $O$-mannosylated extracellular domains and phosphatidylinositol (PI)4,5-bisphosphate, which recruits the $\mathrm{N}$ terminal domains of the Rom1/2-guanine nucleotide exchange factors through the plasma membrane, the sensors stimulate nucleotide exchange on Rho1 [102,105]. The various effectors of Rho1 include $\beta$-1,3-glucan synthase, $\beta-1,3-$ glucan synthase activity, and Pkc1-activated MAPK cascade [104].

In summary, CWPs have a wide range of diverse functions that contribute to virulence, to maintenance of wall structure to ensure cellular integrity remains intact, and to sensing and transmitting signals from the environment. Many CWPs have been functionally characterized and their amino acid sequences are known, but only a handful have had their structures fully elucidated. Structure has a functional implication and understanding CWP structure can increase our knowledge of their functions, including roles in cell wall biogenesis.

\section{Fungal Cell Wall Remodeling and Signaling Pathways That Are Activated in Response to Stress}

C. albicans has been shown to grow at a high concentration of caspofungin a phenomenon called paradoxical growth. Paradoxical growth, in C. albicans is associated with induced cell aggregation and an increase in cell volume and cell wall chitin content [108]. In C. auris, however, it only induced an increase in cell wall chitin content [108]. Genes encoding Fks1 and Fks2 harboring the single nucleotide polymorphisms hot spot regions have been identified in C. auris [108]. The Fks2 carries the F635Y mutation that confers intrinsic echinocandin resistance on Candida glabrata [108]. Interestingly, C. auris RNA-seq data showed that paradoxical growth activates genes encoding cell membrane proteins and GPI-modified proteins required for cell wall damage response, chitin synthase, and 
MAPKs such as Mkc1, and Hog1 involved in maintaining cell wall integrity [108]. Fungal pathogens activate a lot of pathways to successfully adapt to caspofugin stress.

Deletion of cell wall biosynthetic pathway genes in fungi often results in increased susceptibility of the cell wall to wall perturbing agents as well as alterations in chitin and $\beta-1,3$-glucan contents and linkages in the cell wall, synthesis of new wall proteins, and changes in the crosslinking to alternative wall polysaccharides $[109,110]$. Inhibition of $\beta$ 1,3 -glucan synthesis has been associated with altered crosslinking of chitin to $\beta$-1,6-glucanGPI-modified proteins in the cell wall [109]. The amount of chitin $\rightarrow \beta$-glucan $\leftarrow$ GPI-CWP complexes in the cell wall increased to $40 \%$ in wall defective mutants, indicating this is a repair mechanism protecting the cell wall from degrading enzymes and other stresses [109]. Most cell wall restructuring processes do not involve activation of the signaling pathways. For example, the carbon-source-induced alteration in osmotic tolerance in C. albicans was shown to be independent of the CWI pathways, but rather mediated by alterations in the architecture and biophysical properties of the cell wall [111]. However, during the cell wall response to most stressors, signals that indicate weaknesses in the wall are received by the surface sensors and transmitted leading to activation of the corresponding CWI pathways. In Saccharomyces cerevisiae and C. albicans, signaling pathways are activated in response to a wide range of stresses such as CFW, harsh temperatures, oxygen starvation, host immune response during infection and antifungal such as echinocandins, altered nutrient levels, and carbon source [109,112-114]. Cell wall stress response is mediated through the protein kinase $\mathrm{C}, \mathrm{PKC}$ cell integrity mitogen-activated protein (MAP) kinase cascade, and its downstream transcription factors [112,114,115] (Figure 1). Other MAP kinase cascades, the high osmolarity glycerol response, HOG, and Candida ERK-like kinase, Cek1 mediated pathways, have also been shown to play a role in the cell wall reconstruction process $[112,116,117]$ (Figure 1). MAP kinase defective C. albicans mutants display attenuated virulence in infection models showing that MAP kinase pathways are also important for virulence [118-120].

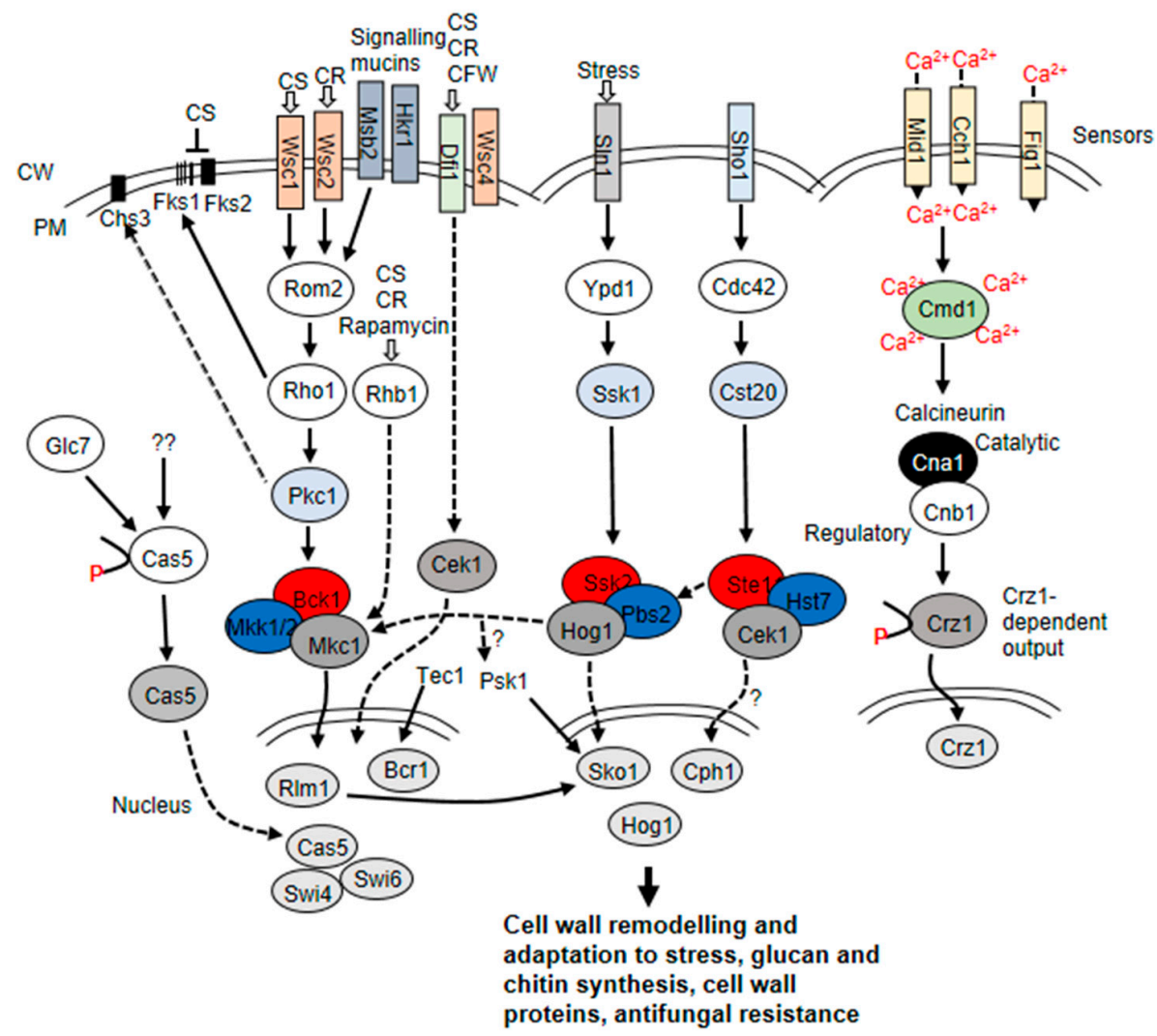

Figure 1. Signaling pathways that regulate cell wall remodeling of S. cerevisiae and C. albicans. The Hog1, Cek1, and Pkc MAP kinase cascades and the $\mathrm{Ca}^{2+} /$ calcineurin signaling pathway control a number of 
cellular processes including cell wall synthesis and maintenance. Upstream membrane sensors of the MAP kinase cascades include Wsc family, Dfi1, Sho1, and Sln1, detect signals reporting weakened cell wall or alterations in the wall, and convey the signal to the downstream components of the pathway. The PKC pathway plays an important role in response to caspofungin and activates Rho1, a regulatory sub-unit of $\beta$-1,3-glucan synthase. Rhb1, an Rheb-related GTPase, activate the CWI MAP kinase Mkc1 in response to cell wall stress. An Rhb1 deletion mutant is hypersensitive to cell wall stress and to rapamycin [121]. Rho1 activates protein kinase C, which phosphorylates and activates Bck1 in the MAP kinase cascade. Bck1 in turn activates the MAP kinase kinases Mkk1/2, which then phosphorylate Mkc1, which may hypothetically target Rlm1 in C. albicans. Although the Mkc1-Rlm1 relationship has been shown in S. cerevisiae, there is no evidence in C. albicans that RIm1 is downstream of the Pkc pathway. A number of transcription factors contribute to the echinocandin stress response including Cas5 and Bcr1 [54]. In C. albicans, Cas5 is activated through an unknown mechanism involving dephosphorylation by Glc7 phosphatase [122]. Cas5 interacts with Swi4 and Swi6 to activate Cas5-dependent gene transcription leading to the upregulation of genes involved in cell biogenesis/integrity and cellular metabolism [122]. Cas5 and Efg1 have been shown to interact in response to caspofungin stress. Efg1 regulates the transcriptional response to cell wall damage by caspofungin [123]. C. albicans efg $1 \Delta / \Delta$ mutant is hypersensitive to caspofungin [123,124]. Cas5 and Efg1 coregulate the expression of caspofungin-inducible genes. Cek1 pathway impinges on cell wall regulation and has also been implicated in systemic candidiasis [119,125]. C. albicans Dfi1, a homologue of S. cerevisiae Mid2/Mtl1 is known to partly activate the MAP kinase Cek1 and confer tolerance to caspofungin, CR, and CFW [126]. A Dfi1 deletion mutant is severely affected in invasive filamentation and virulence in a murine infection model. Msb2 in cooperation with Sho1 is also thought to play a role in Cek1 activation [127]. It is predicted that the transcription factor, Cph1 a homologue of $S c S t e l 2$, is downstream of the Cek1 mediated pathway $[112,119,127]$. Cph1 is associated with regulation of filamentation [127]. The Rlm1 and Bcr1 transcription factors control the expression of a number of cell wall-related genes $[34,128]$ with Bcr1 playing a dominant role in the regulation of biofilm formation by controlling expression of several important adhesins. In C. albicans, the Rlm1 activation mechanism is unknown, but once localized in the nucleus, activated Rlm1 leads to the upregulation of genes involves in cell wall biogenesis/integrity, macromolecular localization, and organelle localization [129]. Putative Rlm1 binding motifs in the promoters of CHS2 and CHS8 contribute to their cell wall stress-activated regulation $[10,130,131]$. In S. cerevisiae, Pkc1 is involved in targeting Chs3 to the plasma membrane in response to heat shock $[129,132]$. Significant re-wiring of signaling pathways is evident in C. albicans, compared to the S. cerevisiae paradigm, for example, the role of the Sko1 transcription factor in response to caspofungin is independent of Hog1 MAP kinase, but involves the Psk1 PAK kinase [133] and Rlm1. In C. albicans, Sko1 regulates the expression of some genes involved in cell wall biogenesis and remodeling, and osmoadaptation [133]. Sko1 binding motif has been identified for regulating Sko1-dependent genes. Sko1 also binds to its motif to promote self-activation. The calcineurin pathway is activated by calcium that may enter the cells through membrane-localized channels Cch1 and Mid1 or a third minor channel Fig1. Alternatively, the pathway may be activated by calcium released from intracellular stores. $\mathrm{Ca}^{2+}$ binds to and activates calmodulin (Cmd1) that in turn activates the phosphatase calcineurin. The calcineurin is made up of two sub-units, Cna1 and Cnb1. Calcineurin dephosphorylates the transcription factor Crz1, which moves into the nucleus and induces expression of genes through binding to CDREs (calcium dependent response elements) within their promoter sequences. Two Crz1 DNA binding motifs have been identified in some genes regulated by Crz1. Adapted from $[112,114,126]$. CR = Congo red, $\mathrm{CS}=$ caspofungin, $\mathrm{CFW}$ calcofluor white, $\mathrm{CWM}=$ cell wall matrix, $\mathrm{PM}=$ plasma membrane.

There is some redundancy in the regulatory networks responding to echinocandininduced cell wall damage where more than one transcription factor controls overlapping sets of downstream target genes to control changes in the cell wall [54,122,133,134]. Three transcription factors, Cas5, Sko1, and Rlm1 have been implicated in echinocandin-induced cell wall damage signaling [54,133].

Cas5 has been shown to be involved in cell wall remodeling in C. albicans during cell growth, morphology, and virulence $[54,122,135,136]$. C. albicans cas $5 \Delta / \Delta$ mutants and in- 
cluding mutants with a missense mutation in Cas5 DNA-binding domain is hypersensitive to caspofungin and other cell wall stressors such as CFW [54,122]. A cas5 $\Delta / \Delta$ deletion mutant has also been shown to have attenuated virulence in both murine and invertebrate models of systemic candidiasis [135]. Genome-wide microarray studies showed that Cas5 regulates about $50 \%$ of the highly expressed caspofungin-inducible genes, including some cell wall integrity genes [54]. Studies using RNA polymerase II chromatin immunoprecipitation and sequencing analyses showed that the number of caspofungin-inducible genes is markedly higher and genes with cell wall-associated functions were markedly overrepresented [122]. Furthermore, Cas5 was found to regulate over $60 \%$ of caspofungin-inducible genes, including those involved in cell wall integrity [122].

Information on the upstream regulation of Cas5 is limited in C. albicans, but available data suggest that Cas5 is dephosphorylated by phosphatase Glc7 following caspofungininduced cell wall damage [122]. The study further showed that upon dephosphorylation of Cas5, it is activated and interacts with Swi4 and Swi6 to activate the transcription of Cas5-dependent genes [122]. This leads to the upregulation of genes involved in cell wall synthesis/integrity and cell metabolism [122].

Cas5 together with Efg1 regulate the transcriptional response to cell wall damage by caspofungin [123]. Efg1 is a member of the APSES family of basic helix-loop-helix transcriptional regulators that is proposed to function downstream of the cAMP/protein kinase A (PKA) pathway to induce a hyphal transcription program $[137,138]$. Likewise, Efg1 is important for transcriptional responses to echinocandins and C. albicans efg $1 \Delta / \Delta$ mutant is hypersensitive to caspofungin [124]. Efg1 also required for the induction of CAS5 in response to cell wall damage by caspofungin [125]. Deletion of EFG1 in a cas5 $\Delta / \Delta$ mutant exacerbates caspofungin hypersensitivity and make caspofugin-resistant $C$. albicans sensitive again. The ectopical expression of $C A S 5$ could not salvage the growth defect of $C$. albicans efg $1 \Delta / \Delta$ mutant treated with caspofungin [123]. Genome wide transcription profiling of $C$. albicans cas $5 \Delta / \Delta$ and $e f g 1 \Delta / \Delta$ mutants using RNA-Seq showed that Cas5 and Efg1 can coregulate the expression of caspofungin-inducible genes and can also independently regulate some genes [123]. Using yeast two-hybrid and in vivo immunoprecipitation, Cas5 and Efg1 were shown to interact and bind to the promoter of some caspofungin-inducible genes to coordinately activate their expression [123].

Efg1 has also been shown to regulate Czf1 expression [139,140]. Czf1, a C. albicans zinc finger cluster transcription factor, is required for white-opaque switching and filamentation [141]. Efg1 and Czf1 interact in a yeast two-hybrid experiment [140] and coordinate responses to farnesol during quorum sensing and white-opaque thermal dimorphism [142]. In the screen of a library of genetically activated forms of zinc cluster transcription factors, hyperactive Czf1 was found to have a cell wall associated function in C. albicans [143]. Hyperactive Czf1 drives the expression of many CWPs with cell wall associated functions that can induce a physical change in the cell wall architecture and rescue the hypersensitivity of different CWI partway deletion mutants to cell wall perturbing agents [143]. In addition, C. albicans $c z f 1 \Delta / \Delta$ mutant is hypersensitive to caspofungin [143].

Downstream of the Pkc pathway is the transcription factor, Rlm1. Rlm1 has been extensively studied in S. cerevisiae where it is the main transcriptional regulator of the Pkc CWI pathway $[144,145]$. However, our understanding of the function of the protein is limited in C. albicans. C. albicans rlm $1 \Delta / \Delta$ mutant is hypersensitive to CFW and Congo red [54] and analysis of mutant cell wall composition compared to wild type showed marked reduction in mannan composition and an increase in chitin levels [128]. This suggested that Rlm1 is involved in caspofungin induced CWI signaling. These characteristics of $r \operatorname{lm} 1 \Delta / \Delta$ in C. albicans have not been observed in S. cerevisiae, showing divergence of these orthologues [128]. In C. glabrata, which is more closely related to $S$. cerevisiae than $C$. albicans, $r \operatorname{lm} 1 \Delta / \Delta, m k k 1 \Delta / \Delta$, and $b c k 1 \Delta / \Delta$ mutants are sensitive to caspofungin, but not to CFW or Congo red [146] and the full influence of this pathway on cell wall regulation is yet to be studied. Genome-wide microarray studies in C. albicans showed that Rlm1 only induced the expression of five genes under basal condition and only two of these 
genes were caspofungin-inducible [54]. Another genome-wide study demonstrated that Rlm1 regulated the expression of 773 genes under basal conditions [128] and some of the highly upregulated genes have cell wall associated function. These data suggest that Rlm1 may have a more general regulatory role in controlling cell wall associated gene during non-stressed physiological activities. Genome-wide ChIP Seq data revealed that Rlm1-target genes encode proteins that have cell wall-associated function [134]. Rlm1 bound to the upstream intergenic regions of 25 genes and 18 of the genes were highly caspofungin-inducible [134]. Furthermore, a $r \operatorname{lm} 1 \Delta / \Delta$ mutant attenuated virulence in a murine model of systemic candidiasis [128].

Orthologues of Pkc pathway are conserved in C. albicans; however, it is not known if the Mkc1 directly or indirectly activates Rlm1. Genomic, biochemical, and cellular data suggest circuit rewiring in Rlm1 and Sko1 CWI signaling [134]. Sko1 function has been extensively studied in S. cerevisiae and shown to be part of the MAP kinase high osmolarity glycerol, Hog, signaling pathway with a role in osmotic and oxidative stress responses [147]. The Hog pathway in C. albicans is associated with pathogenicity traits and it is involved in the control of both pathogenic and commensal state programs [148]. Sko1 function as the regulator of osmotic stress is conserved in C. albicans and it is phophorylated by the MAP kinase Hog1 following osmotic shock [133]. However, Sko1 regulates genes in C. albicans whose orthologues in S. cerevisiae are not involved in osmotic stress response, therefore showing circuitry rewiring [149]. Sko1 function in regulating the oxidative stress response is also conserved in C. albicans [150].

A sko1 $\Delta / \Delta$ mutant is hypersensitive to caspofungin, but not to Congo red, CFW, or SDS [148,150], suggesting Sko1 may not have such a global role in cell wall architecture as Rlm1 or Cas5. Microarray and RT-qPCR data demonstrated that Sko1 regulates 81 caspofungin-inducible genes and 26 of these genes are upregulated by Sko1 [133]. Several of the genes regulated by Sko1 have cell wall-associated function (PGA13 and CRH11), and cell metabolism functions [133,134].

The upstream regulatory mechanisms controlling Sko1 expression in C. albicans are more complex than in S. cerevisiae, where the Hog pathway principally regulates Sko1 transcriptional activity. Caspofungin-induced Sko1 activity is independent of Hog pathway function [133]. RT-qPCR data demonstrated that caspofungin markedly induces SKO1 transcription and this requires the glucose-partitioning PAS kinase, Psk1 [133], but Psk1 does not regulate transcription directly. Microarray data indicate that Rlm1 regulates SKO1 expression under basal conditions [128]. Furthermore, caspofungin-induced SKO1 expression is markedly reduced in $r \operatorname{lm} 1 \Delta / \Delta$ mutant but not in cas5 $\Delta / \Delta$ mutant. It is unknown if Psk1 binds directly to Rlm1 to regulate its activation of $S K O 1$ expression. However, a DNA-binding consensus has been identified in the Sko1 promoter sequence for regulating Sko1 inducible genes and also for autoactivation of SKO1 [134].

The Hog pathway has not been well studied in other Candida species. However, in clinical strains of $C$. auris, Hog1 and Ssk1 have been shown to have variable activities, which suggested some sort of genetic flexibility with effects on cell wall function and stress adaptation [151]. A C. auris ssk $1 \Delta / \Delta$ hog $1 \Delta / \Delta$ mutant had altered tolerance to caspofungin and amphotericin B, with increased echinocandin susceptibility [151]. The mutant also had altered cell wall mannan content and altered hyper-resistance to cell wall stressors [151]. Targeting these two signaling components of the Hog pathway may provide options for an effective combination therapy or enhancement of echinocandin susceptibility.

Phosphotransferase regulator Ypd1 and phosphatase Ptp2 have been identified as the Sko1 targets following caspofungin treatment of C. albicans [134]. Both Ypd1 and Ptp2 are known to inhibit the Hog pathway, indicating that Sko1 blocks the Hog pathway following caspofungin treatment $[152,153]$. There is also cross communication between the Hog1 and Cek1 pathways under basal condition [154] and C. albicans hog $1 \Delta / \Delta$ mutants have constitutively higher levels of Cek1 phosphorylation [117].

The Cek1 pathway is involved in cell pathogenesis and participate in cell wall construction $[155,156]$. Cell surface signals that activate the Cek1 pathway are transmitted 
by membrane bound sensor: Sho1, Msb2, and Opy2 [154-156], and mediated through Cph1 and Tec1 [157,158]. Signals through the sensors trigger stimulus through Cst20 to the Ste11-Hst7-Cek1 MAPK cascade [119]. Deletion of any of these downstream elements as well as Cph1 does not affect filamentation [159]. Cek1 has also been shown to target another transcription factor, Ace2 to upregulate genes encoding protein $O$-mannosyltransferases in response to defective protein $\mathrm{N}$ - or $\mathrm{O}$-glycosylation activities [160]. Cell surface proteins are post-translationally modified to maintain cell wall structure. Genes encoding components in the Cek1 pathway, MSB2, CST20, HST7, CEK1, and ACE2 are Ace2 targets, indicating Ace2-mediated transcriptional upregulation of pathway genes under $\mathrm{N}$-glycosylation stress [160].

In C. albicans and most other fungi, cell damage through the inhibition of $\beta-1,3-$ glucans synthesis triggers compensatory chitin synthesis [101,114,161-163]. We have shown that $\mathrm{Pkc}, \mathrm{Hog}$, and $\mathrm{Ca}^{2+}$ signaling pathways co-ordinately regulate chitin synthesis in response to cell wall stress $[72,110,163]$. These pathways regulate $C H S$ gene expression and chitin synthesis individually and in concert, leading to rearrangement of wall macromolecules in response to cell wall stresses [110]. A lacZ reporter gene was fused to the putative promoters of each of the CHS genes of $\mathrm{C}$. albicans to monitor the expression of $\mathrm{CHS}$ genes when treated with cell wall perturbing agents such as CFW and showed that exogenous $\mathrm{Ca}^{2+}$, which induces the calcineurin pathway, activated all the CHS genes in a Crz1-dependent manner [110]. Crz1 is the downstream transcription factor in the $\mathrm{Ca}^{2+} /$ calcineurin signaling pathway. Treating C. albicans cells with CFW, which activates the Pkc pathway, results in a three-fold increase in chitin content [101]. However, hyper-stimulation of CHS gene expression was observed when Pkc and $\mathrm{Ca}^{2+}$ pathways were simultaneously activated, and this resulted in increased chitin in the cell wall [110]. In S. cerevisiae and C. albicans, the Pkc and Hog MAP kinase cascades and the $\mathrm{Ca}^{2+}$ / calcineurin pathway have been shown to regulate CWPs, such as Sed1, Pst1, Crh1, Cwp1, Ssr1, Yps1, Pir1, and Pir3, involved in cell wall remodeling activities [51,134,145,164-167].

The $\mathrm{Ca}^{2+}$ / calcineurin signaling pathway is implicated in the activation of cell wall remodeling processes in response to damage to the cell wall $[52,101]$ (Figure 1). The proposed model for Crz1 regulation in C. albicans is that the influx of $\mathrm{Ca}^{2+}$ activates calcineurin that then dephosphorylates and activates Crz1. The activated Crz1 enters the nucleus and binds to one or both Crz1 binding motifs in the promoter of target genes leading to their expression [168]. Crz1 has been shown to regulate the expression of 34 genes involved in cell wall biosynthesis in response to calcium stress and 12 of these genes encode proteins that are covalently bound to the cell wall: CRH11, UTR2, PGA1, PGA6, PGA13, PGA23, PGA39, PGA52, PGA20, ECM331, PHR2, DFG5 [168]. Microarray and RNA sequencing data have reveal that Crz1 binds in vitro and in vivo to two identified motifs (calcineurin dependent response element, CDRE) in the promoter of some of the target genes $[53,168]$ to induce their expression. The promoter of 79 genes regulated by Crz1 have two binding motifs for Crz1, while 104 Crz1-regulated genes have only one motif. Meanwhile, 36 Crz1 regulated genes have no discernible Crz1 binding motifs [168]. This suggests that the expression of Crz1 target genes is differentially regulated. It has been shown that Crz1 binds to two motifs in the promoter region of UTR2 to induce expression in response to calcium stress [168].

C. albicans lacking calcineurin is markedly attenuated in virulence in a murine model of systemic candidiasis and cannot survive in the presence of cell membrane stressors [169-171]. C. albicans lacking Crz1, the major target of calcineurin is partially virulent in a murine model of systemic candidiasis, indicating the existence of other calcineurin targets that are important for virulence $[168,172,173]$.

Another determinant of caspofungin sensitivity is the transcription factor, Cup9, which is required for normal caspofungin tolerance in hyphae alone and activates the expression of CWPs with cell wall function [174]. C. albicans cup $9 \Delta / \Delta$ mutant is hypersensitensive to caspofungin stress. RNA-seq data from $C$. albicans cup $9 \Delta / \Delta$ mutant with or without caspofungin demonstrated that Cup9 has a narrow rather than global effect in the cell wall 
damage response and activates proteins such as PGA31 and IFF11 with a known role in cell wall integrity [174].

Generally, these signaling pathways have not been studied in detail in other Candida species; however, in C. glabrata, 3 genes: SLT2, YPK2, and YPK1, whose protein products are involved in cell wall maintenance are associated with in vivo and in vitro echinocandins tolerance [175]. A C. glabrata strain lacking these three genes was susceptible to caspofungin treatment in a murine model of gastrointestinal candidiasis [175]. Furthermore, genes encoding ortholoques of kinases in the cell wall signaling pathway SLT2, MKK1, BEM2, and SW14 were identified in C. glabrata as well as genes encoding ortholoques of calcineurin pathway membrane components: CCH1 and MID1 [146]. Mutants lacking any of these genes were hypersensitive to caspofungin [146]. Deletion of genes representing all stages of CWI pathway from surface sensing to transcription regulation resulted in various degrees of susceptibility to caspofungin and cell wall degrading enzymes [146]. Although more studies are required to understand caspofungin-induced cell wall stress responses in other Candida species, available data suggest similarity in signaling pathways, the response strategies deployed, and the wall proteins involved in maintaining cell wall integrity.

\section{Cell Wall Remodeling in Response to Thermal Stress}

The fungal response to heat shock has been well characterized [176-178]. Temperature stress signals are thought to be sensed by signaling mucins. Signaling mucins are transmembrane glycoproteins that receive and transmit surface signals to signaling pathways (Figure 2). Signaling mucin, Msb2 is known to regulate environmental stress, cell wall biogenesis, and the Cek1 and Pkc pathways in most fungi [178,179]. Msb2 is a global regulator of temperature stress in C. albicans [113]. Msb2 is required for fungal survival and hyphae formation at $42^{\circ} \mathrm{C}$. Msb2 also regulates temperature-dependent activation of genes involved in MAP kinase and unfolded protein response pathways (Figure 2) [113].

Generally, the temperature stress response is controlled by an essential protein, the heat shock transcription factor, Hsf1, which is phosphorylated upon sudden temperature rise [180]. Following temperature rise from 30 to $42{ }^{\circ} \mathrm{C}, \mathrm{Hsf1}$ is phosphorylated rapidly within $60 \mathrm{~s}$ and upon adaptation, downregulated [181]. Under normal growth conditions, Hsf1 binds as a trimer to heat shock elements (HSEs) in the promoters of target heat shock protein (HSP) genes [182]. When S. cerevisiae or C. albicans cells experience an acute heat shock, Hsf1 is hyper-phosphorylated and activated, resulting in the transcriptional induction of the target HSP genes, thus stimulating cellular adaptation to the thermal insult [183]. Most heat shock proteins, Hsp, are molecular chaperones that promote client proteins folding, assembly, or cellular localization. They also often target unfolded or damaged proteins for degradation [184]. In C. albicans, Hsf1 interacts with Hsp such as Hsp90 under steady-state conditions, and upon thermal shocks, this interaction is strengthened, suggesting existence of a Hsf1-Hsp90 autoregulatory circuit [177]. Hsp90 is localized to the nucleus during elevated temperatures. It is possible that the Hsf1-Hsp90 regulon is critical for the maintenance of thermal homeostasis, not merely for adaptation to acute heat shocks. This suggests that the Hsf1-Hsp90 interaction is important for regulation of short-term responses to heat shock (Figure 2). 


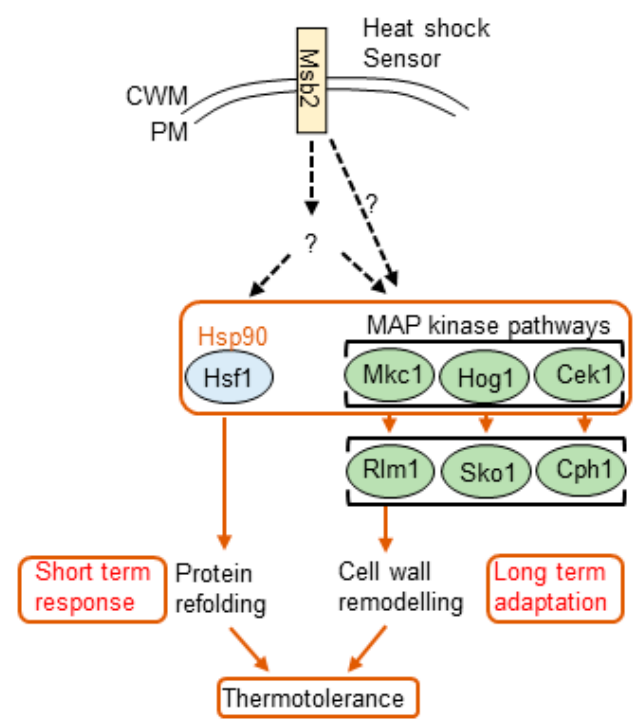

Figure 2. Hsp90 acts as a biological transistor, modulating Hsf1 and the MAPKs transcription factors in response to thermal fluctuations. Msb2 plays a vital role in thermotolerance in C. albicans. The protein transmits heat shock signals through unknown mechanisms that induce downstream targets such as the Pkc pathways in response to high temperatures. Hsf1 activation is required for thermotolerance. The MAP kinase signaling pathways are also required to promote thermotolerance through remodeling the cell wall $[117,185]$. Because Hsp90 coordinates much of this activity, Hsf1, Hog1, Mkc1, and Cek1 are all thought to be Hsp90 client proteins $[177,181]$. Fluctuations in ambient temperature affect interactions between Hsp90 and Hsf1, and probably affect Hsp90 interactions with the MAP kinase transcription factors [181], thus modulating the role of the signaling pathways and thermal adaptation outcome. Temperature upshifts activate Hsf1, which induces the expression of protein chaperones (HSPs), including Hsp90, which promotes shorter term thermal adaptation. It is thought that Hsp90 then down-regulates Hsf1 and modulates MAP kinase signaling, to alter cell wall architecture, which leads to long term thermotolerance in C. albicans. Adapted from [177]. Broken lines indicate unconfirmed regulatory mechanisms.

Cell wall integrity is compromised at elevated temperatures. Temperature affects cell wall polysaccharide composition and the incorporation levels of covalently anchored proteins [186]. Yeasts cells are thought to adapt to heat stress in the longer term by activating the Hog1, Mkc1, and Cek1 MAP kinase pathways, which contribute to thermotolerance $[177,186]$ (Figure 2). These MAP kinase pathways, even though they contribute to thermal adaptation in the longer term through cell wall remodeling, are not essential for Hsf1 activation. Genetic depletion of Hsp90 affects cell wall remodeling activities, suggesting that Hog1, Mkc1, and Cek1 may be client proteins of Hsp90. Hsp90 is thought to be able to integrate both the short term and longer-term molecular responses that underpin thermotolerance [177] (Figure 2).

In S. cerevisiae, MAP kinase pathways have been shown to contribute to thermotolerance [132,187], through localization of Chs3 to the plasma membrane in response to heat shock [129]. Each of these MAP kinase pathways is known to contribute to cell wall remodeling and mutations that interfere with cell wall synthesis increase sensitivity of C. albicans to elevated temperatures. For example, the deletion of certain protein mannosyltransferases of the PMT family, or the inactivation of $\mathrm{OCH} 1$ can increase susceptibility to temperature $[188,189]$. Furthermore, deletion of SSR1 causes elevated susceptibility to temperatures [60].

In a study, thermal upshift was shown to cause reduced secretion of chitinases and have a huge impact on cell wall $N$ mannan composition [190]. Analysis of the cell wall phospholipomannan moiety revealed reduction in $N$ mannan composition of $\beta$ 1,2-mannose [190]. C. albicans is more susceptible to cell wall stressors when grown at 
$42{ }^{\circ} \mathrm{C}$ [186]. Coping with this thermal stress leads to increased phosphorylation of Mkc1, which mediates activation of the CWI pathways. Consequently, the levels of Sap9, the chitin transglycosylases Crh11 and Utr2, and the cell wall maintenance protein, Ecm33, increased, and cells reinforce their walls with chitin through increased chitin synthesis and reduced chitin degradation [186]. Ecm33 is required for growth at high temperatures and S. cerevisiae and C. albicans ecm $33 \Delta / \Delta$ disruptant strains exhibit a temperature sensitive growth defect [191,192].

The Mkc1, Hog1, and Cek1 signaling pathways and associated cell wall remodeling mannoproteins have been proposed to promote longer term thermotolerance through the maintenance of a robust cell wall (Figure 2).

\section{Echinocandin-Induced Cell Wall Remodeling in Yeast}

$\beta$-1,3-glucan is a hallmark component of most yeast cell walls and is synthesized by $\beta-1,3$-glucan synthase. The protein has an integral membrane catalytic subunit, Fks [193]. C. albicans has three FKS genes, but the main activity is from the FKS1 gene product, Fks1. Fks1 is essential and found in association with the regulatory subunit, Rho1 GTPase [194]. Rho1 is required to activate Fks1 for $\beta-1,3$-glucan synthesis (Figure 1). Echinocandins non-competitively inhibit $\beta$-1,3-glucan synthesis by inhibiting the catalytic function of Fks1, leading to a weak cell wall [195]. Echinocandins are fungicidal against Candida species and resistance to the drug has been predominantly associated with point mutations in the FKS1 gene. However, most yeast have been shown to withstand caspofungin treatment, becoming more tolerant to the drug both in vivo and in vitro by inducing the upregulation of chitin synthesis, the second wall structural polysaccharide [162,163].

Chitin is synthesized by chitin synthase enzymes and C. albicans has four chitin synthase proteins comprising of Chs1, Chs2, Chs3, and Chs8. Elevated cell wall chitin is a cell wall rescue mechanism shown to be orchestrated by the CWI pathways $[101,110,196]$. $\mathrm{Pkc}, \mathrm{Hog}$, and $\mathrm{Ca}^{2+}$ signaling pathways have been shown to control the expression of $\mathrm{CHS} 2$ and CHS8 through binding motifs in their promoter sequences [131]. Hyper-stimulation of CHS gene expression was observed when the three signaling pathways were activated at the same time and this leads to elevated cell wall chitin content [110]. Cell wall mutants with higher basal chitin contents are also less susceptible to caspofungin [60,197]. Chitin synthase proteins can also synthesize alternative septa that restore $C$. albicans capacity to bud during cell wall stress [198].

Genome wide studies have been carried out to study the response of fungal cells to echinocandin drugs treatment and to identify genes whose upregulation is required for adaptive growth in the presence of sub-MIC concentrations of echinocandins. DNA microarrays studies identified genes that are activated in S. cerevisiae and C. albicans when they are challenged with sub-MIC concentrations of caspofungin [54]. The induced genes include those genes that are typically upregulated following the activation of the Pkc pathway. In C. albicans and S. cerevisiae, some of the Pkc pathway signature genes: CRH11/CRH1, ECM331/PST1, DFG5, encode GPI anchored cell surface proteins that have been implicated in cell wall biogenesis or repair [51,55,199-202]. Pga31, a predicted GPI anchored wall protein, is upregulated during caspofungin stress, and pga31 $\Delta / \Delta$ mutants have thinner cell walls, reduced chitin content, and are hypersensitive to caspofungin [60]. Cas5 regulates the expression of some CWPs in response to caspofungin, including Crh11, Ecm331, Pga13, and Pga23 [54]. Pga13 plays a role in cell wall architecture [203] and may be required for cell wall repair.

The phosphorylated form of the Pkc pathway component Mkc1/Slt2 and phosphorylated form of Cek1 have been detected in S. cerevisiae and C. albicans [155] following caspofungin challenge. Furthermore, $C$. albicans $m k c 1 \Delta / \Delta$ mutant is hypersensitive to caspofungin [101]. This suggests that the Pkc pathway is a major signaling pathway for triggering cell wall macromolecule rearrangement in response to caspofungin stress in $S$. cerevisiae and C. albicans $[101,196]$. 


\section{Cell Wall Remodeling and Protein Abundance}

In an analysis of the cell wall proteome of $C$. albicans growing on minimal medium without stress using liquid chromatography-mass spectrometry, LC-MS revealed 21 covalently bound CWPs. Out of the 21 CWPs identified, 19 had predicted GPI anchor sequence with cell wall associated function [204]. In other studies, the proteomics technique was used to study the impact of carbon source on the $C$. albicans cell wall proteome and secretome when cells were grown in minimal medium containing $2 \%$ glucose, lactate, or glucose plus lactate $[73,205]$. The results revealed higher amounts of predicted GPI anchored CWPs with functions in cell wall biogenesis/integrity in the secretomes and proteomes. Major differences were seen in the profiles of secreted and CWPs in lactate and glucose-grown $C$. albicans cells. Many of the differences suggested that specific cellular processes associated with the cell surface such as cell wall remodeling, adherence, and biofilm formation, may be affected by the change in carbon source [73]. The secretome and proteome of lactate grown cells had increased levels of proteins involved in the remodeling of $\beta$-glucan [73]. Lactate grown cells were more adherent, and consequently, more virulent in in vivo models of systemic candidiasis and vaginitis, and display increased resistance to caspofungin as well as other stressors [111]. Lactate signaling regulates glucan masking and modulates the immune response [206]. Furthermore, elevated stress resistance did not correlate with increased activation of the CWI pathways, thus the observed phenotypes may be due to the alteration in the architecture as well as the biochemical and biophysical properties of the cell wall [111]. However, Hog1 or Mkc1 signaling pathways mediate expression of CWPs that promote cell wall elasticity required for adaptation to hyperosmotic stress [52]. Interestingly, alterations in the cell wall in response to different media or carbon sources have been shown to involve changes in the molecular weight of mannoproteins [207]. Mannoproteins from C. albicans cultivated on blood or serum have increased molecular weight, when compared with mannoproteins from cells grown on YPD at 30 and $37{ }^{\circ} \mathrm{C}$ [207].

A microarray study using DAY185 C. albicans strain with or without caspofungin treatment identified 216 caspofungin-inducible genes with an expression change of at least two-fold following 1-h caspofungin treatment [54]. A core set of 34 caspofungin stress inducible genes included genes that are known to be involved in cell wall remodeling such as PGA13, CRH11, and PHR1 [54]. In addition, C. albicans grown in vagina-simulative medium, aerated with a gas mixture reflecting the gas composition in the vaginal environment had five CWPs [Als3, Hwp1, Sim1, Tos1, Utr2) in the wall that were absent in the YPD grown control [38]. However, $\mathrm{O}_{2}$ restriction led to higher levels of the non-GPI protein Pir1, $\beta$-1,3-glucan cross-linking protein, and of the GPI anchor protein, Hwp1, an adhesion protein [38].

Environmental $\mathrm{pH}$ has also been shown to greatly alter the fungal cell wall proteome. Klis lab used a system that mimics mucosal surfaces to investigate the influence of host $\mathrm{pH}$ on C. albicans cell wall proteome [208]. At pH 4.0, yeast cells and pseudohyphae were predominantly seen while at $\mathrm{pH} 7.0$, hyphal growth was mainly seen. Relative quantitation of ${ }^{15} \mathrm{~N}$-labelled CWPs using ESI-FT-MS revealed the identity of 21 covalently linked CWPs, most of which are GPI anchored, excluding Tos1, Mp65, and Pir1. At pH 7.0, Als1, Als3, Hyr1, Phr1, Rbt1, Sod5, and Tos1 were identified, while only the transglycosidase, Phr2 was found at $\mathrm{pH}$ 4.0. Furthermore, at $\mathrm{pH} 4.0,12$ out of the 21 CWPs were overexpressed, whereas at $\mathrm{pH} 7.0,9$ proteins were overexpressed. The proteome of the $C$. albicans cell wall is constantly reshuffled to enable cells to adapt to prevailing environmental conditions. The consequences of not adapting to that changing environment is cell death. This is why the cell wall, and its components, are attractive targets for developing more effective diagnostics and therapeutics.

\section{Perspective}

The covalently bound CWPs in the protein coat are indispensable for the survival of $C$. albicans in the environment and during infection. They also play a major role in the development of biofilms and are regulated by signaling pathways that help remodel the cell 
wall during stress. However, our knowledge of their structure, which may influence their function regarding structure-function relation is limited and our understanding of their exact function in many cases is still poor. This calls for a continued functional analysis of fungal CWPs. The regulatory mechanisms associated with the construction of the cell wall protein coat are not well understood. The precise mechanism of coupling these proteins to cell wall and their method of interaction with wall polysaccharide and other proteins in the cell wall, which may affect their localization and hence their function, are still not clear. Understanding the function and regulatory mechanisms of these CWPs will ultimately inform our knowledge of fungal pathogenesis and host-pathogen interactions.

CWPs have carbohydrate-binding motifs and may thus be involved in cell wall synthesis and remodeling, in biofilm formation, or even in the interaction with host cell receptors or other environmental signals. Most importantly, our knowledge of the exact roles CWPs play in CWI pathways, their downstream signaling activities, and the extent of their involvement in the cross interactions between the pathways during cell wall stress is relatively unexploited. The cell wall proteome can change significantly in response to specific environmental stress, including during infection. The fungal cell wall proteome changes associated with infection conditions need more extensive studies, as the cell wall in vivo is likely to be very different to the wall generated under laboratory growth conditions. Finally, the relative and absolute quantitation of CWPs under host-related conditions and an extensive understanding of their exact structure and functions will be vital in identifying the most suitable diagnostic, therapeutic, and vaccine candidates.

Author Contributions: Conceptualization, C.I. and C.A.M.; original draft preparation, C.I.; review and editing, C.I. and C.A.M. All authors have read and agreed to the published version of the manuscript.

Funding: This research was funded by Abia State University and the University of Aberdeen.

Institutional Review Board Statement: Not applicable.

Informed Consent Statement: Not applicable.

Conflicts of Interest: The authors declare no conflict of interest.

\section{References}

1. Brown, G.D.; Denning, D.W.; Gow, N.A.R.; Levitz, S.M.; Netea, M.G.; White, T.C. Hidden killers: Human fungal infections. Sci. Transl. Med. 2012, 4, 165rv13. [CrossRef]

2. Mayer, F.L.; Wilson, D.; Hube, B. Candida albicans pathogenicity mechanisms. Virulence 2013, 4, 119-128. [CrossRef]

3. D'Enfert, C.; Kaune, A.K.; Alaban, L.R.; Chakraborty, S.; Cole, N.; Delavy, M.; Kosmala, D.; Marsaux, B.; Frois-Martins, R.; Morelli, M.; et al. The impact of the Fungus-Host-Microbiota interplay upon Candida albicans infections: Current knowledge and new perspectives. FEMS Microbiol. Rev. 2021, 45, 1-55.

4. Lenardon, M.D.; Sood, P.; Dorfmueller, H.C.; Brown, A.J.; Gow, N.A. Scalar nanostructure of the Candida albicans cell wall; A molecular, cellular and ultrastructural analysis and interpretation. Cell Surf. 2020, 6, 100047. [CrossRef]

5. Luo, G.; Ibrahim, A.S.; Spellberg, B.; Nobile, C.; Mitchell, A.P.; Fu, Y. Candida albicans Hyr1p confers resistance to neutrophil killing and is a potential vaccine target. J. Infect. Dis. 2010, 201, 1718-1728. [CrossRef]

6. Edwards, J.E., Jr.; Schwartz, M.M.; Schmidt, C.S.; Sobel, J.D.; Nyirjesy, P.; Schodel, F.; Marchus, E.; Lizakowski, M.; DeMontigny, E.A.; Hoeg, J.; et al. A fungal immunotherapeutic vaccine (NDV-3A) for treatment of recurrent vulvovaginal candidiasis-A Phase 2 randomized, double-blind, placebo-controlled trial. Clin. Infect. Dis. 2018, 66, 1928-1936. [CrossRef]

7. Spellberg, B.J.; Ibrahim, A.S.; Avanesian, V.; Fu, Y.; Myers, C.; Phan, Q.T.; Filler, S.G.; Yeaman, M.R.; Edwards, J.E., Jr. Efficacy of the anti-Candida rAls3p-N or rAls1p-N vaccines against disseminated and mucosal candidiasis. J. Infect. Dis. 2006, 194, 256-260. [CrossRef]

8. Klis, F.M.; Sosinska, G.J.; De Groot, P.; Brul, S. Covalently linked cell wall proteins of Candida albicans and their role in fitness and virulence. FEMS Yeast Res. 2009, 9, 1013-1028. [CrossRef]

9. Klis, F.M.; de Groot, P.; Hellingwerf, K. Molecular organization of the cell wall of Candida albicans. Med. Mycol. 2001, 39 (Suppl. S1), 1-8. [CrossRef]

10. Sherrington, S.L.; Sorsby, E.; Mahtey, N.; Kumwenda, P.; Lenardon, M.D.; Brown, I.; Ballou, E.R.; Maccallum, D.M.; Hall, R.A. Adaptation of Candida albicans to environmental $\mathrm{pH}$ induces cell wall remodeling and enhances innate immune recognition. PLoS Pathog. 2017, 13, e1006403. [CrossRef] 
11. Cheng, S.-C.; van de Veerdonk, F.L.; Lenardon, M.; Stoffels, M.; Plantinga, T.; Smeekens, S.; Rizzetto, L.; Mukaremera, L.; Preechasuth, K.; Cavalieri, D.; et al. The dectin-1/inflammasome pathway is responsible for the induction of protective T-helper 17 responses that discriminate between yeasts and hyphae of Candida albicans. J. Leukoc. Biol. 2011, 90, 357-366. [CrossRef]

12. Gow, N.A.R.; Latge, J.-P.; Munro, C.A. The fungal cell wall: Structure, biosynthesis, and function. Microbiol. Spectr. 2017, 5, 267-292. [CrossRef]

13. Kollar, R.; Petrakova, E.; Ashwell, G.; Robbins, P.W.; Cabib, E. Architecture of the yeast cell wall. The linkage between chitin and beta(1->3)-glucan. J. Biol. Chem. 1995, 270, 1170-1178. [CrossRef]

14. Gow, N.A.; Hube, B. Importance of the Candida albicans cell wall during commensalism and infection. Curr. Opin. Microbiol. 2012, 15, 406-412. [CrossRef]

15. Zlotnik, H.; Fernandez, M.P.; Bowers, B.; Cabib, E. Saccharomyces cerevisiae mannoproteins form an external cell wall layer that determines wall porosity. J. Bacteriol. 1984, 159, 1018-1026. [CrossRef]

16. Gow, N.A.; Netea, M.G.; Munro, C.A.; Ferwerda, G.; Bates, S.; Mora-Montes, H.M.; Walker, L.; Jansen, T.; Jacobs, L.; Tsoni, V.; et al. Immune recognition of Candida albicans beta-glucan by dectin-1. J. Infect. Dis. 2007, 196, 1565-1571. [CrossRef]

17. Munro, C.; Richard, M.L. The cell wall: Glycoproteins, remodeling, and regulation. In Candida and Candidiasis, 2nd ed.; Calderone, R.A., Clancy, C.J., Eds.; ASM Press: Washington, DC, USA, 2012; pp. 197-223.

18. De Groot, P.W.; Ram, A.F.; Klis, F.M. Features and functions of covalently linked proteins in fungal cell walls. Fungal Genet. Biol. 2005, 42, 657-675. [CrossRef]

19. Ibe, C.; Walker, L.A.; Gow, N.; Munro, C.A. Unlocking the therapeutic potential of the fungal cell wall: Clinical implications and drug resistance. In Candida albicans: Cellular and Molecular Biology; Prasad, R., Ed.; Springer International Publishing: London, UK, 2017; pp. 313-346. [CrossRef]

20. Orlean, P. Architecture and biosynthesis of the Saccharomyces cerevisiae cell wall. Genetics 2012, 192, 775-818. [CrossRef]

21. Bowman, S.M.; Free, S.J. The structure and synthesis of the fungal cell wall. BioEssays 2006, 28, 799-808. [CrossRef]

22. Ferguson, M.A. The structure, biosynthesis and functions of glycosylphosphatidylinositol anchors, and the contributions of trypanosome research. J. Cell Sci. 1999, 112 Pt 17, 2799-2809. [CrossRef]

23. Kinoshita, T.; Inoue, N. Dissecting and manipulating the pathway for glycosylphosphatidylinositol-anchor biosynthesis. Curr. Opin. Chem. Biol. 2000, 4, 632-638. [CrossRef]

24. Richard, M.L.; Plaine, A. Comprehensive analysis of glycosylphosphatidylinositol-anchored proteins in Candida albicans. Eukaryot. Cell 2007, 6, 119-133. [CrossRef]

25. Ruiz-Herrera, J.; Elorza, M.V.; Valentin, E.; Sentandreu, R. Molecular organization of the cell wall of Candida albicans and its relation to pathogenicity. FEMS Yeast Res. 2006, 6, 14-29. [CrossRef]

26. Kapteyn, J.C.; Van Egmond, P.; Sievi, E.; Ende, H.V.D.; Makarow, M.; Klis, F.M. The contribution of the O-glycosylated protein Pir2p/Hsp150 to the construction of the yeast cell wall in wild-type cells and beta1,6-glucan-deficient mutants. Mol. Microbiol. 1999, 31, 1835-1844. [CrossRef]

27. Zhao, X.; Daniels, K.J.; Oh, S.-H.; Green, C.B.; Yeater, K.M.; Soll, D.R.; Hoyer, L.L. Candida albicans Als3p is required for wild-type biofilm formation on silicone elastomer surfaces. Microbiology 2006, 152, 2287-2299. [CrossRef]

28. Zhao, X.; Oh, S.-H.; Yeater, K.M.; Hoyer, L.L. Analysis of the Candida albicans Als2p and Als4p adhesins suggests the potential for compensatory function within the Als family. Microbiology 2005, 151, 1619-1630. [CrossRef]

29. Hoyer, L.L.; Green, C.B.; Oh, S.H.; Zhao, X. Discovering the secrets of the Candida albicans agglutinin-like sequence (ALS) gene family-A sticky pursuit. Med. Mycol. 2008, 46, 1-15. [CrossRef]

30. Almeida, R.S.; Brunke, S.; Albrecht, A.; Thewes, S.; Laue, M.; Edwards, J.E., Jr.; Filler, S.G.; Hube, B. The hyphal-associated adhesin and invasin Als3 of Candida albicans mediates iron acquisition from host ferritin. PLoS Pathog. 2008, 4, e1000217. [CrossRef]

31. Phan, Q.T.; Myers, C.L.; Fu, Y.; Sheppard, D.C.; Yeaman, M.R.; Welch, W.H.; Ibrahim, A.S.; Edwards, J.E., Jr.; Filler, S.G. Als3 Is a Candida albicans invasin that binds to cadherins and induces endocytosis by host cells. PLoS Biol. 2007, 5, e64. [CrossRef]

32. Laforce-Nesbitt, S.S.; Sullivan, M.A.; Hoyer, L.L.; Bliss, J.M. Inhibition of Candida albicans adhesion by recombinant human antibody single-chain variable fragment specific for Als3p. FEMS Immunol. Med. Microbiol. 2008, 54, 195-202. [CrossRef]

33. Nobile, C.; Schneider, H.A.; Nett, J.E.; Sheppard, D.C.; Filler, S.G.; Andes, D.; Mitchell, A.P. Complementary adhesin function in C. albicans biofilm formation. Curr. Biol. 2008, 18, 1017-1024. [CrossRef] [PubMed]

34. Nobile, C.; Andes, D.; Nett, J.E.; Smith, F.J.; Yue, F.; Phan, Q.-T.; Edwards, J.E., Jr.; Filler, S.G.; Mitchell, A.P. Critical role of Bcr1-dependent adhesins in C. albicans biofilm formation In Vitro and In Vivo. PLoS Pathog. 2006, 2, e63. [CrossRef] [PubMed]

35. Nobile, C.; Mitchell, A.P. Regulation of cell-surface genes and biofilm formation by the C. albicans transcription factor Bcr1p. Curr. Biol. 2005, 15, 1150-1155. [CrossRef]

36. Nobile, C.; Nett, J.E.; Andes, D.; Mitchell, A.P. Function of Candida albicans adhesin Hwp1 in biofilm formation. Eukaryot. Cell 2006, 5, 1604-1610. [CrossRef]

37. Ruben, S.; Garbe, E.; Mogavero, S.; Albrecht-Eckardt, D.; Hellwig, D.; Häder, A.; Krüger, T.; Gerth, K.; Jacobsen, I.D.; Elshafee, O.; et al. Ahr1 and Tup1 contribute to the transcriptional control of virulence-associated genes in Candida albicans. mBio 2020, 11, e00206-20. [CrossRef] [PubMed]

38. Sosinska, G.J.; De Groot, P.; De Mattos, M.J.T.; Dekker, H.L.; de Koster, C.; Hellingwerf, K.J.; Klis, F.M. Hypoxic conditions and iron restriction affect the cell-wall proteome of Candida albicans grown under vagina-simulative conditions. Microbiology 2008, 154 Pt 2, 510-520. [CrossRef] 
39. Staab, J.F.; Bradway, S.D.; Fidel, P.L.; Sundstrom, P. Adhesive and mammalian transglutaminase substrate properties of Candida albicans. HwpScience 1999, 283, 1535-1538. [CrossRef]

40. Xin, H.; Dziadek, S.; Bundle, D.R.; Cutler, J.E. Synthetic glycopeptide vaccines combining beta-mannan and peptide epitopes induce protection against candidiasis. Proc. Natl. Acad. Sci. USA 2008, 105, 13526-13531. [CrossRef]

41. Lain, A.; Elguezabal, N.; Brena, S.; Garcia-Ruiz, J.C.; Del Palacio, A.; Moragues, M.D.; Pontón, J. Diagnosis of invasive candidiasis by enzyme-linked immunosorbent assay using the N-terminal fragment of Candida albicans hyphal wall protein-1. BMC Microbiol. 2007, 7, 35. [CrossRef]

42. Hayek, P.; Dib, L.; Yazbeck, P.; Beyrouthy, B.; Khalaf, R.A. Characterization of Hwp2, a Candida albicans putative GPI-anchored cell wall protein necessary for invasive growth. Microbiol. Res. 2010, 165, 250-258. [CrossRef]

43. Younes, S.; Bahnan, W.; Dimassi, H.; Khalaf, R.A. The Candida albicans Hwp2 is necessary for proper adhesion, biofilm formation and oxidative stress tolerance. Microbiol. Res. 2011, 166, 430-436. [CrossRef] [PubMed]

44. McCall, A.D.; Pathirana, R.; Prabhakar, A.; Cullen, P.J.; Edgerton, M. Candida albicans biofilm development is governed by cooperative attachment and adhesion maintenance proteins. NPJ Biofilms Microbiomes 2019, 5, 1-12. [CrossRef] [PubMed]

45. Fonzi, W.A. PHR1 and PHR2 of Candida albicans encode putative glycosidases required for proper cross-linking of beta-1,3- and beta-1,6-glucans. J. Bacteriol. 1999, 181, 7070-7079. [CrossRef] [PubMed]

46. Mouyna, I.; Fontaine, T.; Vai, M.; Monod, M.; Fonzi, W.A.; Diaquin, M.; Popolo, L.; Hartland, R.P.; Latgé, J.-P. Glycosylphosphatidylinositolanchored glucanosyltransferases play an active role in the biosynthesis of the fungal cell wall. J. Biol. Chem. 2000, 275, 14882-14889. [CrossRef] [PubMed]

47. Kovacova, K.; Degani, G.; Stratilová, E.; Farkaš, V.; Popolo, L. Catalytic properties of Phr family members of cell wall glucan remodeling enzymes: Implications for the adaptation of Candida albicans to ambient pH. FEMS Yeast Res. 2015, 15 , fou011. [CrossRef]

48. Eckert, S.E.; Heinz, W.J.; Zakikhany, K.; Thewes, S.; Haynes, K.; Hube, B.; Mühlschlegel, F.A. PGA4, a GAS homologue from Candida albicans, is up-regulated early in infection processes. Fungal Genet. Biol. 2007, 44, 368-377. [CrossRef]

49. Calderon, J.; Zavrel, M.; Ragni, E.; Fonzi, W.A.; Rupp, S.; Popolo, L. PHR1, a pH-regulated gene of Candida albicans encoding a glucan-remodeling enzyme, is required for adhesion and invasion. Microbiology 2010, 156, 2484-2494. [CrossRef]

50. Cabib, E.; Farkas, V.; Kosík, O.; Blanco, N.; Arroyo, J.; McPhie, P. Assembly of the yeast cell wall: Crh1p AND Crh2p act as transglycosylases in vivo and in vitro. J. Biol. Chem. 2008, 283, 29859-29872. [CrossRef]

51. Pardini, G.; De Groot, P.; Coste, A.; Karababa, M.; Klis, F.M.; de Koster, C.; Sanglard, D. The CRH family coding for cell wall Glycosylphosphatidylinositol proteins with a predicted transglycosidase domain affects cell wall organization and virulence of Candida albicans. J. Biol. Chem. 2006, 281, 40399-40411. [CrossRef]

52. Ene, I.V.; Walker, L.A.; Schiavone, M.; Lee, K.K.; Martin-Yken, H.; Dague, E.; Gow, N.A.R.; Munro, C.A.; Brown, A.J.P. Cell wall remodeling enzymes modulate fungal cell wall elasticity and osmotic stress resistance. mBio 2015, 6, e00986-15. [CrossRef]

53. Karababa, M.; Valentino, E.; Pardini, G.; Coste, A.T.; Bille, J.; Sanglard, D. CRZ1, a target of the calcineurin pathway in Candida albicans. Mol. Microbiol. 2006, 59, 1429-1451. [CrossRef] [PubMed]

54. Bruno, V.M.; Kalachikov, S.; Subaran, R.; Nobile, C.J.; Kyratsous, C.; Mitchell, A.P. Control of the C. albicans cell wall damage response by transcriptional regulator Cas5. PLoS Pathog. 2006, 2, e21. [CrossRef] [PubMed]

55. Ao, J.; Chinnici, J.L.; Maddi, A.; Free, S.J. The N-linked outer chain mannans and the Dfg5p and Dcw1p Endo- $\alpha-1,6-M a n n a n a s e s$ are needed for incorporation of Candida albicans glycoproteins into the cell wall. Eukaryot. Cell 2015, 14, 792-803. [CrossRef] [PubMed]

56. Mancuso, R.; Chinnici, J.; Tsou, C.; Busarajan, S.; Munnangi, R.; Maddi, A. Functions of Candida albicans cell wall glycosidases Dfg5p and Dcw1p in biofilm formation and HOG MAPK pathway. PeerJ 2018, 6, e5685. [CrossRef] [PubMed]

57. Butler, G.; Rasmussen, M.D.; Lin, M.F.; Santos, M.; Sakthikumar, S.; Munro, C.; Rheinbay, E.; Grabherr, M.; Forche, A.; Reedy, J.L.; et al. Evolution of pathogenicity and sexual reproduction in eight Candida genomes. Nature 2009, 459, 657-662. [CrossRef]

58. De Boer, A.D.; de Groot, P.W.; Weindl, G.; Schaller, M.; Riedel, D.; Diez-Orejas, R.; Klis, F.M.; de Koster, C.G.; Dekker, H.L.; Gross, U.; et al. The Candida albicans cell wall protein Rhd3/Pga29 is abundant in the yeast form and contributes to virulence. Yeast 2010, 27, 611-624. [CrossRef] [PubMed]

59. Castillo, L.; Martínez, A.I.; Garcerá, A.; Garcia-Martinez, J.; Ruiz-Herrera, J.; Valentín, E.; Sentandreu, R. Genomic response programs of Candida albicans following protoplasting and regeneration. Fungal Genet. Biol. 2006, 43, 124-134. [CrossRef]

60. Plaine, A.; Walker, L.; Da Costa, G.; Mora-Montes, H.M.; McKinnon, A.; Gow, N.; Gaillardin, C.; Munro, C.; Richard, M.L. Functional analysis of Candida albicans GPI-anchored proteins: Roles in cell wall integrity and caspofungin sensitivity. Fungal Genet. Biol. 2008, 45, 1404-1414. [CrossRef]

61. Frohner, I.E.; Bourgeois, C.; Yatsyk, K.; Majer, O.; Kuchler, K. Candida albicans cell surface superoxide dismutases degrade host-derived reactive oxygen species to escape innate immune surveillance. Mol. Microbiol. 2009, 71, 240-252. [CrossRef]

62. Martchenko, M.; Alarco, A.-M.; Harcus, D.; Whiteway, M. Superoxide dismutases in Candida albicans: Transcriptional regulation and functional characterization of the hyphal-induced SOD5 gene. Mol. Biol. Cell 2004, 15, 456-467. [CrossRef]

63. Albrecht, A.; Felk, A.; Pichova, I.; Naglik, J.; Schaller, M.; De Groot, P.; MacCallum, D.; Odds, F.C.; Schäfer, W.; Klis, F.; et al. Glycosylphosphatidylinositol-anchored proteases of Candida albicans target proteins necessary for both cellular processes and host-pathogen interactions. J. Biol. Chem. 2006, 281, 688-694. [CrossRef] [PubMed] 
64. Moreno-Ruiz, E.; Ortu, G.; De Groot, P.; Cottier, F.; Loussert, C.; Prévost, M.-C.; De Koster, C.; Klis, F.M.; Goyard, S.; D’Enfert, C. The GPI-modified proteins Pga59 and Pga62 of Candida albicans are required for cell wall integrity. Microbiology 2009, 155, 2004-2020. [CrossRef] [PubMed]

65. Perez, A.; Pedros, B.; Murgui, A.; Casanova, M.; Lopez-Ribot, J.L.; Martinez, J.P. Biofilm formation by Candida albicans mutants for genes coding fungal proteins exhibiting the eight-cysteine-containing CFEM domain. FEMS Yeast Res. 2006, 6, 1074-1084. [CrossRef] [PubMed]

66. Braun, B.R.; Head, W.S.; Wang, M.X.; Johnson, A.D. Identification and characterization of tup1-regulated genes in Candida albicans. Genetics 2000, 156, 31-44. [CrossRef] [PubMed]

67. Weissman, Z.; Kornitzer, D. A family of Candida cell surface haem-binding proteins involved in haemin and haemoglobin-iron utilization. Mol. Microbiol. 2004, 53, 1209-1220. [CrossRef] [PubMed]

68. Kuznets, G.; Vigonsky, E.; Weissman, Z.; Lalli, D.; Gildor, T.; Kauffman, S.J.; Turano, P.; Becker, J.; Lewinson, O.; Kornitzer, D. A relay network of extracellular heme-binding proteins drives, C. albicans iron acquisition from hemoglobin. PLOS Pathog. 2014, 10, e1004407. [CrossRef] [PubMed]

69. Martínez, A.I.; Castillo, L.; Garcerá, A.; Elorza, M.V.; Valentín, E.; Sentandreu, R. Role of Pir1 in the construction of the Candida albicans cell wall. Microbiology 2004, 150, 3151-3161. [CrossRef] [PubMed]

70. Pietrella, D.; Lupo, P.; Rachini, A.; Sandini, S.; Ciervo, A.; Perito, S.; Bistoni, F.; Vecchiarelli, A. A Candida albicans mannoprotein deprived of its mannan moiety is efficiently taken up and processed by human dendritic cells and induces T-cell activation without stimulating proinflammatory cytokine production. Infect. Immun. 2008, 76, 4359-4367. [CrossRef]

71. Willaert, R.G. Adhesins of Yeasts: Protein Structure and Interactions. J. Fungi 2018, 4, 119. [CrossRef]

72. Munro, C.A. Chitin and glucan, the yin and yang of the fungal cell wall, implications for antifungal drug discovery and therapy. Adv. Appl. Microbiol. 2013, 83, 145-172. [CrossRef]

73. Ene, I.V.; Heilmann, C.J.; Sorgo, A.G.; Walker, L.A.; de Koster, C.G.; Munro, C.A.; Klis, F.M.; Brown, A.J.P. Carbon source-induced reprogramming of the cell wall proteome and secretome modulates the adherence and drug resistance of the fungal pathogen Candida albicans. Proteomics 2012, 12, 3164-3179. [CrossRef] [PubMed]

74. Rolli, E.; Ragni, E.; Calderon, J.; Porello, S.; Fascio, U.; Popolo, L. Immobilization of the glycosylphosphatidylinositol-anchored gas1 protein into the chitin ring and septum is required for proper morphogenesis in yeast. Mol. Biol. Cell 2009, 20, 4856-4870. [CrossRef]

75. Sarthy, A.V.; McGonigal, T.; Coen, M.; Frost, D.J.; Meulbroek, J.A.; Goldman, R.C. Phenotype in Candida albicans of a disruption of the BGL2 gene encoding a 1,3- $\beta$-glucosyltransferase. Microbiology 1997, 143, 367-376. [CrossRef] [PubMed]

76. Cantarel, B.L.; Coutinho, P.M.; Rancurel, C.; Bernard, T.; Lombard, V.; Henrissat, B. The Carbohydrate-Active EnZymes database (CAZy): An expert resource for Glycogenomics. Nucleic Acids Res. 2009, 37, D233-D238. [CrossRef] [PubMed]

77. Klis, F.M.; Boorsma, A.; De Groot, P. Cell wall construction in Saccharomyces cerevisiae. Yeast 2006, 23, 185-202. [CrossRef] [PubMed]

78. Klis, F.M.; Brul, S.; De Groot, P.W.J. Covalently linked wall proteins in ascomycetous fungi. Yeast 2010, 27, 489-493. [CrossRef]

79. Dranginis, A.M.; Rauceo, J.M.; Coronado, J.E.; Lipke, P.N. A Biochemical guide to yeast adhesins: Glycoproteins for social and antisocial occasions. Microbiol. Mol. Biol. Rev. 2007, 71, 282-294. [CrossRef]

80. Kapteyn, J.C.; Hoyer, L.; Hecht, J.E.; Muller, W.H.; Andel, A.; Verkleij, A.J.; Makarow, M.; Ende, H.V.D.; Klis, F.M. The cell wall architecture of Candida albicans wild-type cells and cell wall-defective mutants. Mol. Microbiol. 2000, 35, 601-611. [CrossRef]

81. García-Sánchez, S.; Aubert, S.; Iraqui, I.; Janbon, G.; Ghigo, J.-M.; D’Enfert, C. Candida albicans Biofilms: A Developmental State Associated With Specific and Stable Gene Expression Patterns. Eukaryot. Cell 2004, 3, 536-545. [CrossRef]

82. Garcerá, A.; Martínez, A.I.; Castillo, L.; Elorza, M.V.; Sentandreu, R.; Valentín, E. Identification and study of a Candida albicans protein homologous to Saccharomyces cerevisiae Ssr1p, an internal cell-wall protein. Microbiology 2003, 149 Pt 8, $2137-2145$. [CrossRef]

83. Li, F.; Palecek, S.P. EAP1, a Candida albicans gene involved in binding human epithelial cells. Eukaryot. Cell 2003, 2, 1266-1273. [CrossRef] [PubMed]

84. Weissman, Z.; Shemer, R.; Conibear, E.; Kornitzer, D. An endocytic mechanism for haemoglobin-iron acquisition in Candida albicans. Mol. Microbiol. 2008, 69, 201-217. [CrossRef] [PubMed]

85. Munro, C. Candida albican cell wall mediated virulence. The Yeast Handbook Series; In Pathogenic Yeast; Ashbee, R.H., Bignell, E.M., Eds.; Springer: Berlin/Heidelberg, Germany, 2010; pp. 69-95.

86. Gaur, N.K.; Klotz, S.A. Accessibility of the peptide backbone of protein ligands is a key specificity determinant in Candida albicans SRS adherence. Microbiology 2004, 150, 277-284. [CrossRef] [PubMed]

87. Sheppard, D.C.; Yeaman, M.R.; Welch, W.H.; Phan, Q.T.; Fu, Y.; Ibrahim, A.S.; Filler, S.G.; Zhang, M.; Waring, A.J.; Edwards, J.E. Functional and structural diversity in the Als protein family of Candida albicans. J. Biol. Chem. 2004, 279, 30480-30489. [CrossRef]

88. Calderone, R.A.; Fonzi, W.A. Virulence factors of Candida albicans. Trends Microbiol. 2001, 9, 327-335. [CrossRef]

89. Staab, J.F.; Datta, K.; Rhee, P. Niche-specific requirement for hyphal wall protein 1 in virulence of Candida albicans. PLoS ONE 2013, 8, e80842. [CrossRef]

90. Naglik, J.R.; Moyes, D.L.; Wachtler, B.; Hube, B. Candida albicans interactions with epithelial cells and mucosal immunity. Microbes Infect. 2011, 13, 963-976. [CrossRef]

91. Zhu, W.; Filler, S.G. Interactions of Candida albicans with epithelial cells. Cell Microbiol. 2010, 12, 273-282. [CrossRef] 
92. Wächtler, B.; Citiulo, F.; Jablonowski, N.; Förster, S.; Dalle, F.; Schaller, M.; Wilson, D.; Hube, B. Candida albicans-epithelial interactions: Dissecting the roles of active penetration, induced endocytosis and host factors on the infection process. PLoS ONE 2012, 7, e36952. [CrossRef]

93. Naglik, J.R.; Challacombe, S.J.; Hube, B. Candida albicans secreted aspartyl proteinases in virulence and pathogenesis. Microbiol. Mol. Biol. Rev. 2003, 67, 400-428. [CrossRef]

94. Taylor, B.N.; Hannemann, H.; Sehnal, M.; Biesemeier, A.; Schweizer, A.; Röllinghoff, M.; Schröppel, K. Induction of SAP7 correlates with virulence in an intravenous infection model of candidiasis but not in a vaginal infection model in mice. Infect. Immun. 2005, 73, 7061-7063. [CrossRef] [PubMed]

95. Hube, B.; Naglik, J. Candida albicans proteinases: Resolving the mystery of a gene family. Microbiology 2001, 147 Pt 8, $1997-2005$. [CrossRef]

96. Schild, L.; Heyken, A.; de Groot, P.W.; Hiller, E.; Mock, M.; de Koster, C.; Horn, U.; Rupp, S.; Hube, B. Proteolytic cleavage of covalently linked cell wall proteins by Candida albicans Sap9 and Sap10. Eukaryot. Cell. 2011, 10, 98-109. [CrossRef] [PubMed]

97. Ramage, G.; Saville, S.P.; Thomas, D.P.; López-Ribot, J.L. Candida Biofilms: An Update. Eukaryot. Cell 2005, 4, 633-638. [CrossRef] [PubMed]

98. Nobile, C.J.; Nett, J.E.; Hernday, A.D.; Homann, O.R.; Deneault, J.S.; Nantel, A.; Andes, D.R.; Johnson, A.D.; Mitchell, A.P. Biofilm matrix regulation by Candida albicans Zap1. PLoS Biol. 2009, 7, e1000133. [CrossRef]

99. Green, C.B.; Cheng, G.; Chandra, J.; Mukherjee, P.; Ghannoum, M.A.; Hoyer, L.L. RT-PCR detection of Candida albicans ALS gene expression in the reconstituted human epithelium (RHE) model of oral candidiasis and in model biofilms. Microbiology 2004, 150 Pt 2, 267-275. [CrossRef]

100. Brown, A.J.P.; Budge, S.; Kaloriti, D.; Tillmann, A.; Jacobsen, M.D.; Yin, Z.; Ene, I.V.; Bohovych, I.; Sandai, D.; Kastora, S.; et al. Stress adaptation in a pathogenic fungus. J. Exp. Biol. 2014, 217, 144-155. [CrossRef] [PubMed]

101. Walker, L.A.; Munro, C.; de Bruijn, I.; Lenardon, M.D.; McKinnon, A.D.; Gow, N.A.R. Stimulation of chitin synthesis rescues Candida albicans from echinocandins. PLoS Pathog. 2008, 4, e1000040. [CrossRef]

102. Heinisch, J.J.; Dupres, V.; Wilk, S.; Jendretzki, A.; Dufrene, Y.F. Single-molecule atomic force microscopy reveals clustering of the yeast plasma-membrane sensor Wsc1. PLoS ONE 2010, 5, e11104. [CrossRef]

103. Rodicio, R.R.; Heinisch, J.J. Together we are strong-cell wall integrity sensors in yeasts. Yeast 2010, 27, 531-540. [CrossRef] [PubMed]

104. Levin, D.E. Regulation of cell wall biogenesis in Saccharomyces cerevisiae: The cell wall integrity signaling pathway. Genetics 2011, 189, 1145-1175. [CrossRef] [PubMed]

105. Dupres, V.; Alsteens, D.; Wilk, S.; Hansen, B.; Heinisch, J.J.; Dufrêne, Y. The yeast Wsc1 cell surface sensor behaves like a nanospring In Vivo. Nat. Chem. Biol. 2009, 5, 857-862. [CrossRef]

106. Philip, B.; Levin, D.E. Wsc1 and Mid2 are cell surface sensors for cell wall integrity signaling that act through Rom2, a Guanine Nucleotide Exchange Factor for Rho1. Mol. Cell. Biol. 2001, 21, 271-280. [CrossRef] [PubMed]

107. Rajavel, M.; Philip, B.; Buehrer, B.M.; Errede, B.; Levin, D.E. Mid2 is a putative sensor for cell integrity signaling in Saccharomyces cerevisiae. Mol. Cell. Biol. 1999, 19, 3969-3976. [CrossRef]

108. Lara-Aguilar, V.; Rueda, C.; García-Barbazán, I.; Varona, S.; Monzón, S.; Jiménez, P.; Cuesta, I.; Zaballos, Á.; Zaragoza, Ó. Adaptation of the emerging pathogenic yeast Candida auris to high caspofungin concentrations correlates with cell wall changes. Virulence 2021, 12, 1400-1417. [CrossRef] [PubMed]

109. Kapteyn, J.C.; Ram, A.F.; Groos, E.M.; Kollar, R.; Montijn, R.C.; Ende, H.V.D.; Llobell, A.; Cabib, E.; Klis, F.M. Altered extent of cross-linking of beta1,6-glucosylated mannoproteins to chitin in Saccharomyces cerevisiae mutants with reduced cell wall beta1,3-glucan content. J. Bacteriol. 1997, 179, 6279-6284. [CrossRef]

110. Munro, C.A.; Selvaggini, S.; de Bruijn, I.; Walker, L.; Lenardon, M.D.; Gerssen, B.; Milne, S.; Brown, A.J.; Gow, N. The PKC, HOG and $\mathrm{Ca}^{2+}$ signalling pathways co-ordinately regulate chitin synthesis in Candida albicans. Mol. Microbiol. 2007, 63, 1399-1413. [CrossRef]

111. Ene, I.V.; Adya, A.K.; Wehmeier, S.; Brand, A.C.; MacCallum, D.M.; Gow, N.A.; Brown, A.J.P. Host carbon sources modulate cell wall architecture, drug resistance and virulence in a fungal pathogen. Cell Microbiol. 2012, 14, 1319-1335. [CrossRef]

112. Monge, R.A.; Román, E.; Nombela, C.; Pla, J. The MAP kinase signal transduction network in Candida albicans. Microbiology 2006, 152 Pt 4, 905-912. [CrossRef]

113. Saraswat, D.; Kumar, R.; Pande, T.; Edgerton, M.; Cullen, P.J. Signalling mucin Msb2 Regulates adaptation to thermal stress in Candida albicans. Mol. Microbiol. 2016, 100, 425-441. [CrossRef]

114. Walker, L.A.; Gow, N.; Munro, C.A. Fungal echinocandin resistance. Fungal Genet. Biol. 2010, 47, 117-126. [CrossRef] [PubMed]

115. Navarro-García, F.; Eisman, B.; Fiuza, S.; Nombela, C.; Pla, J. The MAP kinase Mkc1p is activated under different stress conditions in Candida albicans. Microbiology 2005, 151 Pt 8, 2737-2749. [CrossRef]

116. Bermejo, C.; Rodríguez, E.; Garcia, R.; Peña, J.M.R.; de la Concepción, M.L.R.; Rivas, C.; Arias, P.; Nombela, C.; Posas, F.; Arroyo, J. The Sequential Activation of the Yeast HOG and SLT2 Pathways is required for cell survival to cell wall stress. Mol. Biol. Cell 2008, 19, 1113-1124. [CrossRef] [PubMed]

117. Eisman, B.; Alonso-Monge, R.; Román, E.; Arana, D.; Nombela, C.; Pla, J. The Cek1 and Hog1 Mitogen-Activated Protein Kinases Play Complementary Roles in Cell wall biogenesis and chlamydospore formation in the fungal pathogen Candida albicans. Eukaryot. Cell 2006, 5, 347-358. [CrossRef] [PubMed] 
118. Diez-Orejas, R.; Molero, G.; Navarro-Garcia, F.; Pla, J.; Nombela, C.; Sanchez-Perez, M. Reduced virulence of Candida albicans MKC1 mutants: A role for mitogen-activated protein kinase in pathogenesis. Infect Immun. 1997, 65, 833-837. [CrossRef] [PubMed]

119. Csank, C.; Schröppel, K.; Leberer, E.; Harcus, D.; Mohamed, O.; Meloche, S.; Thomas, D.Y.; Whiteway, M. Roles of the Candida albicans mitogen-activated protein kinase homolog, Cek1p, in hyphal development and systemic candidiasis. Infect. Immun. 1998, 66, 2713-2721. [CrossRef] [PubMed]

120. Alonso-Monge, R.; Navarro-Garcia, F.; Molero, G.; Diez-Orejas, R.; Gustin, M.; Pla, J.; Sanchez, M.; Nombela, C. Role of the mitogen-activated protein kinase Hog1p in morphogenesis and virulence of Candida albicans. J. Bacteriol. 1999, 181, 3058-3068. [CrossRef] [PubMed]

121. Tsao, C.-C.; Chen, Y.-T.; Lan, C.-Y. A small G protein Rhb1 and a GTPase-activating protein Tsc2 involved in nitrogen starvationinduced morphogenesis and cell wall integrity of Candida albicans. Fungal Genet. Biol. 2009, 46, 126-136. [CrossRef] [PubMed]

122. Xie, J.L.; Qin, L.; Miao, Z.; Grys, B.T.; Diaz, J.D.L.C.; Ting, K.; Krieger, J.R.; Tong, J.; Tan, K.; Leach, M.D.; et al. The Candida albicans transcription factor Cas5 couples stress responses, drug resistance and cell cycle regulation. Nat. Commun. 2017, 8, 1-18. [CrossRef]

123. Xiong, K.; Su, C.; Sun, Q.; Lu, Y. Efg1 and Cas5 orchestrate cell wall damage response to caspofungin in Candida albicans. Antimicrob. Agents Chemother. 2021, 65, e01584-20. [CrossRef] [PubMed]

124. Gregori, C.; Glaser, W.; Frohner, I.E.; Reinoso-Martin, C.; Rupp, S.; Schuller, C.; Kuchler, K. Efg1 Controls caspofungin-induced cell aggregation of Candida albicans through the adhesin Als1. Eukaryot Cell. 2011, 10, 1694-1704. [CrossRef] [PubMed]

125. Zucchi, P.C.; Davis, T.R.; Kumamoto, C.A. A Candida albicans cell wall-linked protein promotes invasive filamentation into semi-solid medium. Mol. Microbiol. 2010, 76, 733-748. [CrossRef] [PubMed]

126. Dichtl, K.; Samantaray, S.; Wagener, J. Cell wall integrity signalling in human pathogenic fungi. Cell. Microbiol. 2016, 18, 1228-1238. [CrossRef] [PubMed]

127. Liu, H.; Kohler, J.; Fink, G.R. Suppression of hyphal formation in Candida albicans by mutation of a STE12 homolog. Science 1994, 266, 1723-1726. [CrossRef]

128. Silva, Y.B.D.; Vaz, C.; Pereira, J.; Carneiro, C.; Nogueira, E.; Correia, A.; Carreto, L.; Silva, S.; Faustino, A.; Pais, C.; et al. Participation of Candida albicans transcription factor RLM1 in cell wall biogenesis and virulence. PLoS ONE 2014, 9, e86270. [CrossRef]

129. Valdivia, R.H.; Schekman, R. The yeasts Rho1p and Pkc1p regulate the transport of chitin synthase III (Chs3p) from internal stores to the plasma membrane. Proc. Natl. Acad. Sci. USA 2003, 100, 10287-10292. [CrossRef]

130. Lenardon, M.D.; Munro, C.; Gow, N.A. Chitin synthesis and fungal pathogenesis. Curr. Opin. Microbiol. 2010, 13, 416-423. [CrossRef]

131. Lenardon, M.D.; Lesiak, I.; Munro, C.; Gow, N.A.R. Dissection of the Candida albicans class I chitin synthase promoters. Mol. Genet. Genom. 2009, 281, 459-471. [CrossRef] [PubMed]

132. Kamada, Y.; Jung, U.S.; Piotrowski, J.; Levin, D. The protein kinase C-activated MAP kinase pathway of Saccharomyces cerevisiae mediates a novel aspect of the heat shock response. Genes Dev. 1995, 9, 1559-1571. [CrossRef]

133. Rauceo, J.M.; Blankenship, J.R.; Fanning, S.; Hamaker, J.J.; Deneault, J.S.; Smith, F.J.; Nantel, A.; Mitchell, A.P.; Bloom, K. Regulation of the Candida albicans cell wall damage response by transcription factor Sko1 and PAS kinase Psk1. Mol. Biol. Cell. 2008, 19, 2741-2751.

134. Heredia, M.Y.; Ikeh, M.A.C.; Gunasekaran, D.; Conrad, K.A.; Filimonava, S.; Marotta, D.H.; Nobile, C.J.; Rauceo, J.M. An expanded cell wall damage signaling network is comprised of the transcription factors RIm1 and Sko1 in Candida albicans. PLoS Genet. 2020, 16, e1008908. [CrossRef]

135. Chamilos, G.; Nobile, C.J.; Bruno, V.M.; Lewis, R.E.; Mitchell, A.P.; Kontoyiannis, D.P. Candida albicans Cas5, a regulator of cell wall integrity, is required for virulence in murine and toll mutant fly models. J. Infect. Dis. 2009, 200, 152-157. [CrossRef] [PubMed]

136. Vasicek, E.M.; Berkow, E.L.; Bruno, V.M.; Mitchell, A.P.; Wiederhold, N.; Barker, K.S.; Rogers, P.D. Disruption of the transcriptional regulator Cas5 results in enhanced killing of Candida albicans by fluconazole. Antimicrob. Agents Chemother. 2014, 58, 6807-6818. [CrossRef] [PubMed]

137. Bockmuhl, D.P.; Ernst, J.F. A potential phosphorylation site for an A-type kinase in the Efg1 regulator protein contributes to hyphal morphogenesis of Candida albicans. Genetics 2001, 157, 1523-1530. [CrossRef]

138. Nantel, A.; Dignard, D.; Bachewich, C.; Harcus, D.; Marcil, A.; Bouin, A.-P.; Sensen, C.W.; Hogues, H.; Hoog, M.V.H.; Gordon, P.; et al. Transcription profiling of Candida albicans cells undergoing the yeast-to-hyphal transition. Mol. Biol. Cell 2002, 13, 3452-3465. [CrossRef]

139. Zordan, R.E.; Galgoczy, D.J.; Johnson, A.D. Epigenetic properties of white-opaque switching in Candida albicans are based on a self-sustaining transcriptional feedback loop. Proc. Natl. Acad. Sci. USA 2006, 103, 12807-12812. [CrossRef]

140. Noffz, C.S.; Liedschulte, V.; Lengeler, K.; Ernst, J.F. Functional mapping of the Candida albicans Efg1 regulator. Eukaryot. Cell 2008, 7, 881-893. [CrossRef] [PubMed]

141. Stichternoth, C.; Ernst, J.F. Hypoxic Adaptation by Efg1 Regulates biofilm formation by Candida albicans. Appl. Environ. Microbiol. 2009, 75, 3663-3672. [CrossRef] 
142. Langford, M.L.; Hargarten, J.C.; Patefield, K.D.; Marta, E.; Blankenship, J.; Fanning, S.; Nickerson, K.W.; Atkin, A.L. Candida albicans Czf1 and Efg1 coordinate the response to farnesol during quorum sensing, white-opaque thermal dimorphism, and cell death. Eukaryot. Cell 2013, 12, 1281-1292. [CrossRef]

143. Mottola, A.; Ramírez-Zavala, B.; Hünniger, K.; Kurzai, O.; Morschhäuser, J. The zinc cluster transcription factor Czf1 regulates cell wall architecture and integrity in Candida albicans. Mol. Microbiol. 2021, 116, 483-497. [CrossRef]

144. Dodou, E.; Treisman, R. The Saccharomyces cerevisiae MADS-box transcription factor Rlm1 is a target for the Mpk1 mitogenactivated protein kinase pathway. Mol. Cell. Biol. 1997, 17, 1848-1859. [CrossRef]

145. Jung, U.S.; Levin, D. Genome-wide analysis of gene expression regulated by the yeast cell wall integrity signalling pathway. Mol. Microbiol. 1999, 34, 1049-1057. [CrossRef]

146. Rosenwald, A.G.; Arora, G.; Ferrandino, R.; Gerace, E.L.; Mohammednetej, M.; Nosair, W.; Rattila, S.; Subic, A.Z.; Rolfes, R. Identification of genes in Candida glabrata conferring altered responses to caspofungin, a cell wall synthesis inhibitor. G3 Genes Genomes Genet. 2016, 6, 2893-2907. [CrossRef]

147. Saito, H.; Posas, F. Response to Hyperosmotic Stress. Genetics 2012, 192, 289-318. [CrossRef] [PubMed]

148. Román, E.; Correia, I.; Prieto, A.D.; Alonso, R.; Pla, J. The HOG MAPK pathway in Candida albicans: More than an osmosensing pathway. Int. Microbiol. 2019, 23, 23-29. [CrossRef] [PubMed]

149. Marotta, D.H.; Nantel, A.; Sukala, L.; Teubl, J.R.; Rauceo, J.M. Genome-wide transcriptional profiling and enrichment mapping reveal divergent and conserved roles of Sko1 in the Candida albicans osmotic stress response. Genomics 2013, 102, 363-371. [CrossRef] [PubMed]

150. Alonso-Monge, R.; Román, E.; Arana, D.M.; Prieto, A.D.; Urrialde, V.; Nombela, C.; Pla, J. The Sko1 protein represses the yeast-to-hypha transition and regulates the oxidative stress response in Candida albicans. Fungal Genet. Biol. $2010,47,587-601$. [CrossRef] [PubMed]

151. Shivarathri, R.; Jenull, S.; Stoiber, A.; Chauhan, M.; Mazumdar, R.; Singh, A.; Nogueira, F.; Kuchler, K.; Chowdhary, A.; Chauhan, $\mathrm{N}$. The two-component response regulator Ssk1 and the mitogen-activated protein Kinase Hog1 control antifungal drug resistance and cell wall architecture of Candida auris. mSphere 2020, 5, e00973-20. [CrossRef]

152. Day, A.M.; Smith, D.A.; Ikeh, M.A.C.; Haider, M.; Herrero-De-Dios, C.M.; Brown, A.J.; Morgan, B.A.; Erwig, L.P.; Maccallum, D.M.; Quinn, J. Blocking two-component signalling enhances Candida albicans virulence and reveals adaptive mechanisms that counteract sustained SAPK activation. PLoS Pathog. 2017, 13, e1006131. [CrossRef] [PubMed]

153. Mavrianos, J.; Desai, C.; Chauhan, N. Two-component histidine phosphotransfer protein Ypd1 Is not essential for viability in Candida albicans. Eukaryot. Cell 2014, 13, 452-460. [CrossRef]

154. Herrero, C.; Alonso-Monge, R.; Pla, J. The lack of upstream elements of the Cek1 and Hog1 mediated pathways leads to a synthetic lethal phenotype upon osmotic stress in Candida albicans. Fungal Genet. Biol. 2014, 69, 31-42. [CrossRef] [PubMed]

155. Román, E.; Cottier, F.; Ernst, J.F.; Pla, J. Msb2 signaling mucin controls activation of Cek1 mitogen-activated protein kinase in Candida albicans. Eukaryot. Cell 2009, 8, 1235-1249. [CrossRef]

156. Román, E.; Nombela, C.; Pla, J. The Sho1 adaptor protein links oxidative stress to morphogenesis and cell wall biosynthesis in the fungal pathogen Candida albicans. Mol. Cell. Biol. 2005, 25, 10611-10627. [CrossRef]

157. Ramírez-Zavala, B.; Weyler, M.; Gildor, T.; Schmauch, C.; Kornitzer, D.; Arkowitz, R.; Morschhäuser, J. Activation of the Cph1dependent MAP kinase signaling pathway induces white-opaque switching in Candida albicans. PLoS Pathog. 2013, 9, e1003696. [CrossRef]

158. Sahni, N.; Yi, S.; Daniels, K.J.; Huang, G.; Srikantha, T.; Soll, D.R. Tec1 mediates the pheromone response of the white phenotype of Candida albicans: Insights into the evolution of new signal transduction pathways. PLoS Biol. 2010, 8, e1000363. [CrossRef]

159. Huang, H.; Harcus, D.; Whiteway, M. Transcript profiling of a MAP kinase pathway in C. albicans. Microbiol. Res. 2008, 163, 380-393. [CrossRef] [PubMed]

160. Van Wijlick, L.; Swidergall, M.; Brandt, P.; Ernst, J.F. Candida albicans responds to glycostructure damage by Ace2-mediated feedback regulation of Cek1 signaling. Mol. Microbiol. 2016, 102, 827-849. [CrossRef] [PubMed]

161. Walker, L.A.; Lee, K.K.; Munro, C.A.; Gow, N.A. Caspofungin treatment of Aspergillus fumigatus results in ChsG-dependent upregulation of chitin synthesis and the formation of chitin-rich microcolonies. Antimicrob. Agents Chemother. 2015, 59, 5932-5941. [CrossRef]

162. Lee, K.K.; MacCallum, D.M.; Jacobsen, M.D.; Walker, L.A.; Odds, F.C.; Gow, N.A.R.; Munro, C.A. Elevated cell wall chitin in Candida albicans confers echinocandin resistance In Vivo. Antimicrob. Agents Chemother. 2012, 56, 208-217. [CrossRef]

163. Walker, L.A.; Gow, N.A.R.; Munro, C.A. Elevated chitin content reduces the susceptibility of Candida species to caspofungin. Antimicrob. Agents Chemother. 2013, 57, 146-154. [CrossRef]

164. Cabib, E.; Blanco, N.; Grau, C.; Rodriguez-Pena, J.M.; Arroyo, J. Crh1p and Crh2p are required for the cross-linking of chitin to beta(1-6)glucan in the Saccharomyces cerevisiae cell wall. Mol. Microbiol. 2007, 63, 921-935. [CrossRef]

165. Cabib, E. Two novel techniques for determination of polysaccharide cross-links show that Crh1p and Crh2p attach chitin to both beta(1-6)- and beta(1-3)glucan in the Saccharomyces cerevisiae cell wall. Eukaryot. Cell. 2009, 8, 1626-1636. [CrossRef]

166. Terashima, H.; Yabuki, N.; Arisawa, M.; Hamada, K.; Kitada, K. Up-regulation of genes encoding glycosylphosphatidylinositol (GPI)-attached proteins in response to cell wall damage caused by disruption of FKS1 in Saccharomyces cerevisiae. Mol. Genet. Genom. 2000, 264, 64-74. [CrossRef] [PubMed] 
167. Yoshimoto, H.; Saltsman, K.; Gasch, A.P.; Li, H.X.; Ogawa, N.; Botstein, D.; Brown, P.O.; Cyert, M.S. Genome-wide analysis of gene expression regulated by the calcineurin/Crz1p signaling pathway in Saccharomyces cerevisiae. J. Biol. Chem. 2002, 277, 31079-31088. [CrossRef] [PubMed]

168. Xu, H.; Fang, T.; Omran, R.P.; Whiteway, M.; Jiang, L. RNA sequencing reveals an additional Crz1-binding motif in promoters of its target genes in the human fungal pathogen Candida albicans. Cell Commun. Signal. 2020, 18, 1-14. [CrossRef] [PubMed]

169. Sanglard, D.; Ischer, F.; Marchetti, O.; Entenza, J.; Bille, J. Calcineurin A of Candida albicans: Involvement in antifungal tolerance, cell morphogenesis and virulence. Mol. Microbiol. 2003, 48, 959-976. [CrossRef]

170. Blankenship, J.R.; Wormley, F.L.; Boyce, M.K.; Schell, W.A.; Filler, S.G.; Perfect, J.R.; Heitman, J. Calcineurin is essential for Candida albicans survival in serum and virulence. Eukaryot. Cell. 2003, 2, 422-430. [CrossRef] [PubMed]

171. Cruz, M.C.; Goldstein, A.L.; Blankenship, J.R.; Del Poeta, M.; Davis, D.; Cardenas, M.E.; Perfect, J.R.; McCusker, J.H.; Heitman, J. Calcineurin is essential for survival during membrane stress in Candida albicans. EMBO J. 2002, 21, 546-559. [CrossRef]

172. Jiang, L.; Alber, J.; Wang, J.; Du, W.; Yang, X.; Li, X.; Sanglard, D.; Geyer, J. The Candida albicans plasma membrane protein Rch1p, a member of the vertebrate SLC10 carrier family, is a novel regulator of cytosolic $\mathrm{Ca}^{2+}$ homoeostasis. Biochem. J. 2012, 444, 497-502. [CrossRef] [PubMed]

173. Mille, C.; Janbon, G.; Delplace, F.; Ibata-Ombetta, S.; Gaillardin, C.; Strecker, G.; Jouault, T.; Trinel, P.-A.; Poulain, D. Inactivation of CaMIT1 inhibits Candida albicans phospholipomannan beta-mannosylation, reduces virulence, and alters cell wall protein beta-mannosylation. J. Biol. Chem. 2004, 279, 47952-47960. [CrossRef]

174. Ichikawa, Y.; Bruno, V.M.; Woolford, C.A.; Kim, H.; Do, E.; Brewer, G.; Mitchell, A.P. Environmentally contingent control of Candida albicans cell wall integrity by transcriptional regulator Cup9. Genetics 2021, 218, iyab075. [CrossRef]

175. Garcia-Rubio, R.; Hernandez, R.Y.; Clear, A.; Healey, K.R.; Shor, E.; Perlin, D.S. Critical assessment of cell wall integrity factors contributing to in vivo echinocandin tolerance and resistance in Candida glabrata. Front. Microbiol. 2021, 12, 702779. [CrossRef]

176. Brown, D.H., Jr.; Giusani, A.D.; Chen, X.; Kumamoto, C.A. Filamentous growth of Candida albicans in response to physical environmental cues and its regulation by the unique CZF1 gene. Mol. Microbiol. 1999, 34, 651-662. [CrossRef]

177. Leach, M.D.; Budge, S.; Walker, L.; Munro, C.; Cowen, L.; Brown, A.J. Hsp90 orchestrates transcriptional regulation by Hsf1 and cell wall remodelling by MAPK signalling during thermal adaptation in a pathogenic yeast. PLoS Pathog. 2012, 8, e1003069. [CrossRef] [PubMed]

178. Puri, S.; Kumar, R.; Chadha, S.; Tati, S.; Conti, H.R.; Hube, B.; Cullen, P.J.; Edgerton, M. Secreted aspartic protease cleavage of Candida albicans Msb2 activates Cek1 MAPK signaling affecting biofilm formation and oropharyngeal candidiasis. PLoS ONE 2012, 7, e46020. [CrossRef]

179. Cullen, P.J.; Sabbagh, W.; Graham, E.; Irick, M.M.; Van Olden, E.K.; Neal, C.; Delrow, J.; Bardwell, L.; Sprague, G.F., Jr. A signaling mucin at the head of the Cdc42- and MAPK-dependent filamentous growth pathway in yeast. Genes Dev. 2004, 18, 1695-1708. [CrossRef] [PubMed]

180. Sorger, P.; Pelham, H.R. Yeast heat shock factor is an essential DNA-binding protein that exhibits temperature-dependent phosphorylation. Cell 1988, 54, 855-864. [CrossRef]

181. Leach, M.; Tyc, K.M.; Brown, A.J.P.; Klipp, E. Modelling the regulation of thermal adaptation in Candida albicans, a major fungal pathogen of humans. PLOS ONE 2012, 7, e32467. [CrossRef] [PubMed]

182. Jakobsen, B.K.; Pelham, H.R. Constitutive binding of yeast heat shock factor to DNA in vivo. Mol. Cell Biol. 1988, 8, 5040-5042. [CrossRef]

183. Sorger, P.; Lewis, M.J.; Pelham, H.R.B. Heat shock factor is regulated differently in yeast and HeLa cells. Nature 1987, 329, 81-84. [CrossRef] [PubMed]

184. Feder, M.E.; Hofmann, G.E. Heat-shock proteins, molecular chaperones, and the stress response: Evolutionary and ecological physiology. Annu. Rev. Physiol. 1999, 61, 243-282. [CrossRef] [PubMed]

185. Navarro-García, F.; Monge, R.A.; Rico, H.; Pla, J.; Sentandreu, R.; Nombela, C. A role for the MAP kinase gene MKC1 in cell wall construction and morphological transitions in Candida albicans. Microbiology 1998, 144 Pt 2, 411-424. [CrossRef]

186. Heilmann, C.J.; Sorgo, A.G.; Mohammadi, S.; Sosinska, G.J.; de Koster, C.; Brul, S.; De Koning, L.J.; Klis, F.M. Surface Stress Induces a Conserved Cell Wall Stress response in the pathogenic fungus Candida albicans. Eukaryot. Cell 2013, 12, $254-264$. [CrossRef]

187. Winkler, A.; Arkind, C.; Mattison, C.P.; Burkholder, A.; Knoche, K.; Ota, I. Heat stress activates the yeast high-osmolarity glycerol mitogen-activated protein kinase pathway, and protein tyrosine phosphatases are essential under heat stress. Eukaryot. Cell 2002, 1, 163-173. [CrossRef] [PubMed]

188. Prill, S.K.-H.; Klinkert, B.; Timpel, C.; Gale, C.A.; Schröppel, K.; Ernst, J.F. PMT family of Candida albicans: Five protein mannosyltransferase isoforms affect growth, morphogenesis and antifungal resistance. Mol. Microbiol. 2005, 55, 546-560. [CrossRef] [PubMed]

189. Bates, S.; Hughes, H.B.; Munro, C.; Thomas, W.P.; MacCallum, D.; Bertram, G.; Atrih, A.; Ferguson, M.; Brown, A.J.; Odds, F.C.; et al. Outer chain n-glycans are required for cell wall integrity and virulence of Candida albicans. J. Biol. Chem. 2006, 281, 90-98. [CrossRef]

190. Okawa, Y.; Goto, K. Antigenicity of cell wall mannans of Candida albicans and Candida stellatoidea cultured at high temperatures in BACTEC medium. Biol. Pharm. Bull. 2006, 29, 1723-1727. [CrossRef] [PubMed] 
191. Terashima, H.; Hamada, K.; Kitada, K. The localization change of Ybr078w/Ecm33, a yeast GPI-associated protein, from the plasma membrane to the cell wall, affecting the cellular function. FEMS Microbiol. Lett. 2003, 218, 175-180. [CrossRef] [PubMed]

192. Gil-Bona, A.; Reales-Calderon, J.A.; Giraldo, C.M.P.; Martinez, R.; Monteoliva, L.; Gil, C. The cell wall protein Ecm33 of Candida albicans is involved in chronological life span, morphogenesis, cell wall regeneration, stress tolerance, and host-cell interaction. Front. Microbiol. 2016, 7, 64. [CrossRef] [PubMed]

193. Douglas, C.M.; Foor, F.; Marrinan, J.A.; Morin, N.; Nielsen, J.B.; Dahl, A.M.; Mazur, P.; Baginsky, W.; Li, W.; El-Sherbeini, M. The Saccharomyces cerevisiae FKS1 (ETG1) gene encodes an integral membrane protein which is a subunit of 1,3-beta-D-glucan synthase. Proc. Natl. Acad. Sci. USA 1994, 91, 12907-12911. [CrossRef]

194. Qadota, H.; Python, C.P.; Inoue, S.B.; Arisawa, M.; Anraku, Y.; Zheng, Y.; Watanabe, T.; Levin, D.E.; Ohya, Y. Identification of yeast Rho1p GTPase as a regulatory subunit of 1,3-beta-glucan Synthase. Science 1996, 272, 279-281. [CrossRef]

195. Denning, D.W. Echinocandin antifungal drugs. Lancet 2003, 362, 1142-1151. [CrossRef]

196. Reinoso-Martín, C.; Schüller, C.; Schuetzer-Muehlbauer, M.; Kuchler, K. The yeast protein kinase C cell integrity pathway mediates tolerance to the antifungal drug caspofungin through activation of Slt2p mitogen-activated protein kinase signaling. Eukaryot. Cell 2003, 2, 1200-1210. [CrossRef] [PubMed]

197. Tams, R.N.; Wagner, A.S.; Jackson, J.W.; Gann, E.R.; Sparer, T.E.; Reynolds, T.B. Pathways that synthesize phosphatidylethanolamine impact Candida albicans hyphal length and cell wall composition through transcriptional and posttranscriptional mechanisms. Infect. Immun. 2020, 88. [CrossRef]

198. Walker, L.A.; Lenardon, M.D.; Preechasuth, K.; Munro, C.; Gow, N.A.R. Cell wall stress induces alternative fungal cytokinesis and septation strategies. J. Cell Sci. 2013, 126 Pt 12, 2668-2677. [CrossRef]

199. Blanco, N.; Sanz, A.B.; Peña, J.M.R.; Nombela, C.; Farkas, V.; Hurtado-Guerrero, R.; Arroyo, J. Structural and functional analysis of yeast Crh1 and Crh2 transglycosylases. FEBS J. 2014, 282, 715-731. [CrossRef]

200. Pardo, M.; Monteoliva, L.; Vázquez, P.; Martinez, R.; Molero, G.; Nombela, C.; Gil, C. PST1 and ECM33 encode two yeast cell surface GPI proteins important for cell wall integrity. Microbiology 2004, 150 Pt 12, 4157-4170. [CrossRef]

201. Peña, J.M.R.; Cid, V.J.; Arroyo, J.; Nombela, C. A novel family of cell wall-related proteins regulated differently during the yeast life cycle. Mol. Cell. Biol. 2000, 20, 3245-3255. [CrossRef]

202. Spreghini, E.; Davis, D.A.; Subaran, R.; Kim, M.; Mitchell, A.P. Roles of Candida albicans Dfg5p and Dcw1p Cell Surface Proteins in Growth and Hypha Formation. Eukaryot. Cell 2003, 2, 746-755. [CrossRef] [PubMed]

203. Gelis, S.; de Groot, P.W.; Castillo, L.; Moragues, M.-D.; Sentandreu, R.; Gómez, M.-M.; Valentín, E. Pga13 in Candida albicans is localized in the cell wall and influences cell surface properties, morphogenesis and virulence. Fungal Genet. Biol. 2012, 49, 322-331. [CrossRef] [PubMed]

204. Castillo, L.; Calvo, E.; Martínez, A.I.; Ruiz-Herrera, J.; Valentín, E.; Lopez, J.A.; Sentandreu, R. A study of the Candida albicans cell wall proteome. Proteomics 2008, 8, 3871-3881. [CrossRef] [PubMed]

205. Childers, D.S.; Avelar, G.M.; Bain, J.M.; Pradhan, A.; Larcombe, D.E.; Netea, M.G.; Erwig, L.P.; Gow, N.A.R.; Brown, A.J.P. Epitope shaving promotes fungal immune evasion. mBio 2020, 11, e00984-20. [CrossRef] [PubMed]

206. Ballou, E.R.; Avelar, G.M.; Childers, D.S.; Mackie, J.; Bain, J.M.; Wagener, J.; Kastora, S.L.; Panea, M.D.; Hardison, S.E.; Walker, L.A.; et al. Lactate signalling regulates fungal beta-glucan masking and immune evasion. Nat. Microbiol. 2016, 2, 16238. [CrossRef] [PubMed]

207. Kruppa, M.; Greene, R.R.; Noss, I.; Lowman, D.W.; Williams, D.L. C. albicans increases cell wall mannoprotein, but not mannan, in response to blood, serum and cultivation at physiological temperature. Glycobiology 2011, 21, 1173-1180. [CrossRef] [PubMed]

208. Sosinska, G.J.; De Koning, L.J.; De Groot, P.; Manders, E.M.M.; Dekker, H.L.; Hellingwerf, K.J.; De Koster, C.G.; Klis, F.M. Mass spectrometric quantification of the adaptations in the wall proteome of Candida albicans in response to ambient $\mathrm{pH}$. Microbiology 2011, 157 Pt 1, 136-146. [CrossRef] 